UNIVERSIDADE DE SÃO PAULO

FACULDADE DE ECONOMIA, ADMINISTRAÇÃO E CONTABILIDADE DEPARTAMENTO DE ADMINISTRAÇÃO PROGRAMA DE PÓS-GRADUAÇÃO EM ADMINISTRAÇÃO

O USO DO ORÇAMENTO EMPRESARIAL COMO FERRAMENTA DE APOIO À TOMADA DE DECISÃO E AO CONTROLE GERENCIAL EM INDÚSTRIAS FARMACÊUTICAS DE MÉDIO PORTE

Dariane Reis Fraga Castanheira Orientador: Prof. Dr. Carlos Eduardo de Mori Luporini 
Profa. Dra. Suely Vilela

Reitora da Universidade de São Paulo

Prof. Dr. Carlos Roberto Azzoni

Diretor da Faculdade de Economia, Administração e Contabilidade

Prof. Dr. Isaac Kruglianskas

Chefe do Departamento de Administração

Prof. Lindolfo Galvão Albuquerque

Coordenador do Programa de Pós-Graduação em Administração 


\title{
O USO DO ORÇAMENTO EMPRESARIAL COMO FERRAMENTA DE APOIO À TOMADA DE DECISÃO E AO CONTROLE GERENCIAL EM INDÚSTRIAS FARMACÊUTICAS DE MÉDIO PORTE
}

\author{
Dissertação apresentada ao Departamento de \\ Administração da Faculdade de Economia, \\ Administração e Contabilidade da Universidade \\ de São Paulo como parte dos requisitos para a \\ obtenção do título de Mestre em Administração
}

Orientador: Prof. Dr. Carlos Eduardo de Mori Luporini 
Castanheira, Dariane Reis Fraga

$\mathrm{O}$ uso do orçamento empresarial como ferramenta de apoio à tomada de decisão e ao controle gerencial / Dariane Reis Fraga Castanheira. -São Paulo, 2008.

$103 \mathrm{p}$.

Dissertação (Mestrado) - Universidade de São Paulo, 2008

Bibliografia.

1. Planejamento empresarial 2.Orçamento empresarial 3. Orçamento empresarial - Processos I. Universidade de São Paulo. Faculdade de Economia, Administração e Contabilidade II. Título.

CDD -658.4012 
Dedico este trabalho aos meus pais, Aldary e Dalcione; ao meu esposo, Paulo César, e às minhas irmãs, Ariane e Glaucione. 


\section{AGRADECIMENTOS}

Ao meu orientador, Prof. Dr. Carlos Eduardo de Mori Luporini, as orientações, idéias, conselhos, indicações e apoio na realização desta dissertação.

Ao Prof. Dr. Almir Ferreira de Sousa, as contribuições, não somente como membro da banca de qualificação, mas como amigo e grande incentivador e apoiador.

Ao Prof. Dr. Adelino De Bortoli Neto, as idéias e conselhos.

Ao Prof. Dr. José Roberto Ferreira Savóia, as suas valiosas contribuições.

Ao Prof. Dr. José Luiz Munhoz, as idéias e contribuições.

Ao Prof. Dr. Luiz Paulo Fávero, o apoio e auxílio na escolha do método de pesquisa. 


\section{RESUMO}

Esta dissertação tem como objetivo o estudo do uso do orçamento empresarial como ferramenta de apoio às decisões e ao controle gerencial em indústrias farmacêuticas de médio porte. Como objetivos específicos, este estudo verifica se essas indústrias possuem um sistema de informações contábil-gerenciais adequado à necessidade dos gestores, a adoção de uma estrutura formal para planejamento dos resultados em curto e longo prazos, o modelo aplicado na elaboração do orçamento empresarial e a avaliação dos gestores sobre o processo orçamentário adotado. O referencial teórico apresenta a visão de renomados autores e está dividido em quatro partes. A primeira contempla decisões gerenciais e o sistema de informação contábil-gerencial. A segunda, o planejamento estratégico. Em seguida, o orçamento empresarial e, finalmente, o controle gerencial. A metodologia de pesquisa adotada foi o estudo de caso múltiplo, com a participação de cinco empresas. Os dados foram coletados por meio de entrevistas roteirizadas individuais, realizadas pela pesquisadora, com os gestores administrativo-financeiros dessas empresas. A conclusão apresentada neste trabalho revela que o orçamento empresarial é utilizado como ferramenta de apoio às decisões e ao controle gerencial pelos gestores das cinco empresas e que o processo orçamentário adotado é adequado às necessidades, mas ainda cabem melhorias. 


\begin{abstract}
This dissertation aims at the study of corporate budget as a tool to support the decisions and the management control in medium sized pharmaceutical industries. As specific objectives, the study checks if the industries have a managerial accounting information system that suits the managers' needs, the adoption of a formal structure for the planning of long and short term results, the pattern applied in the elaboration of the corporate budget and the managers' evaluation of the budgetary process that has been adopted. The theoretical reference presents the point of view of renowned authors and it is divided into four parts. The first one describes managerial decisions as well as the managerial accounting information system. The second one is about strategic planning. Then the corporate budget and finally the management control. The adopted research methodology was multiple case study in which five enterprises participated. The data was collected by researchers through individual interviews with administrative-finance managers from the companies. The conclusion presented by this work reveals that the managerial corporate budget is used by managers from the five enterprises as a support tool for the decisions and managerial control and that the adopted budgetary process suits the needs, but there is still the need for improvement.
\end{abstract}




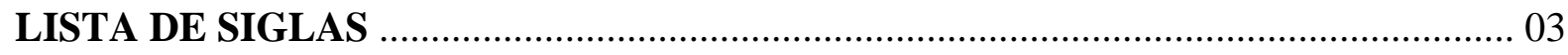

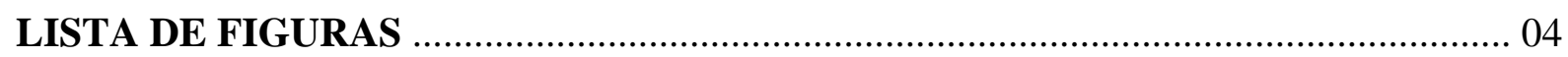

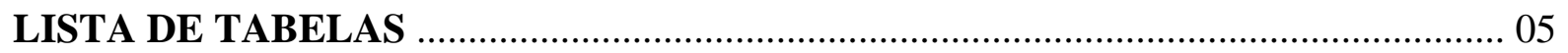

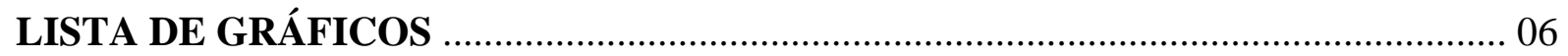

1 INTRODUÇÃO …...................................................................................................... 07

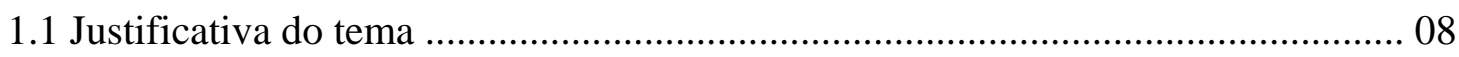

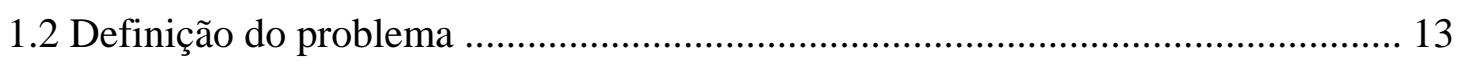

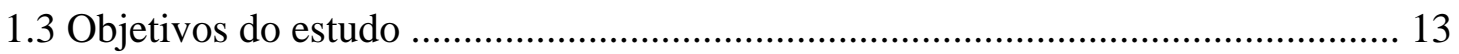

2 REVISÃO TEÓRICA ……........................................................................................ 15

2.1 Sistema de Informação Contábil-Gerencial: apoio às decisões gerenciais .... 16

2.1.1 Decisões Gerenciais ...................................................................... 16

2.1.2 Sistema de Informação Contábil-Gerencial .................................... 18

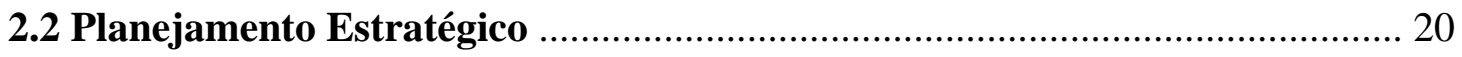

2.2.1 O Planejamento nas Empresas ...................................................... 21

2.2.2 O Planejamento Estratégico .......................................................... 23

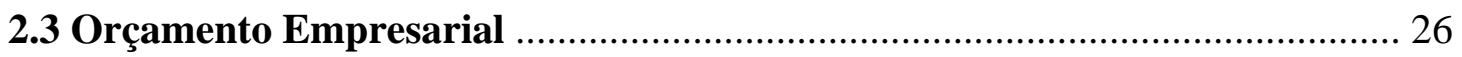

2.3.1 Princípios Gerais de Planejamento ................................................. 27

2.3.2 A Organização do Orçamento ........................................................ 29

2.3.3 Etapas do Processo Orçamentário ................................................... 30

2.3.3.1 Processo Orçamentário: um exemplo da indústria farmacêutica ................................................................... 33

2.3.4 Avaliação, Aprovação e Divulgação do Orçamento .......................... 40

2.3.5 Vantagens e Limitações do Orçamento ........................................... 41 


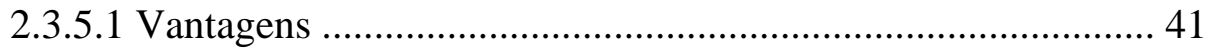

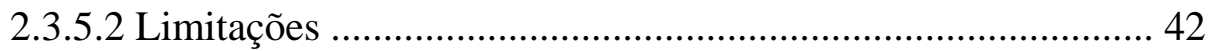

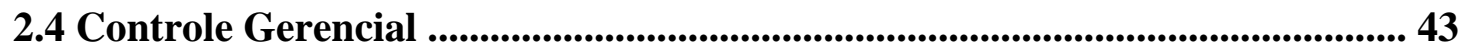

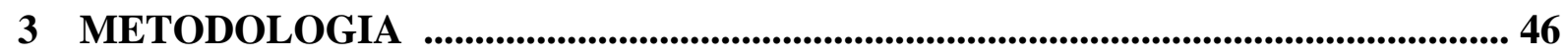

3.1 Caracterização da Pesquisa ........................................................................ 46

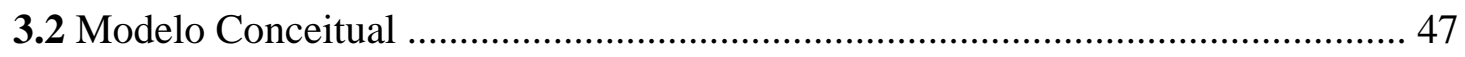

3.2.1 Variáveis de Pesquisa ........................................................................ 48

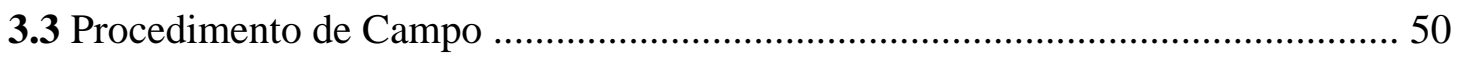

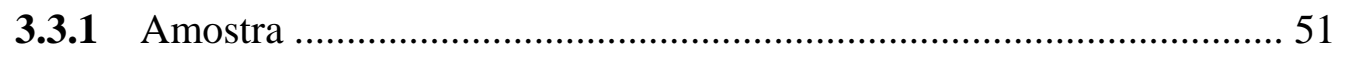

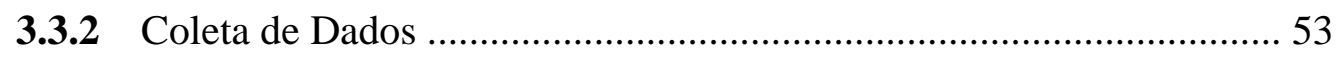

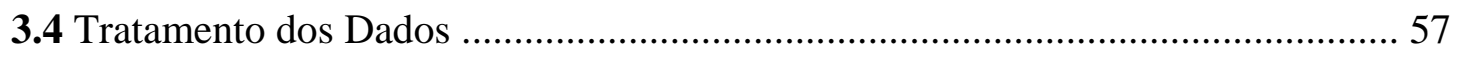

3.5 Limitações do Método ....................................................................................... 57

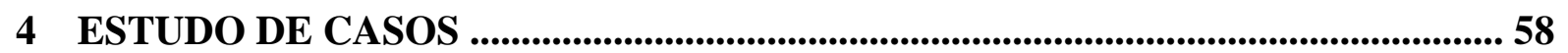

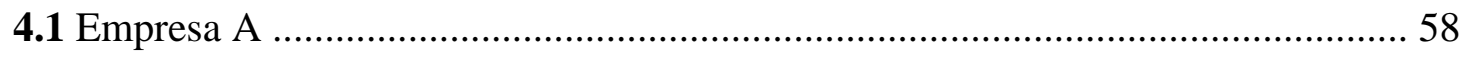

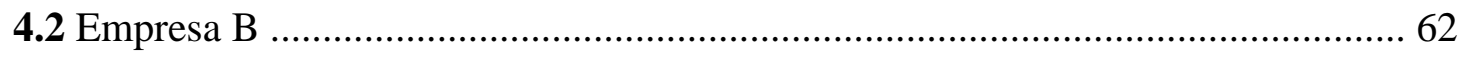

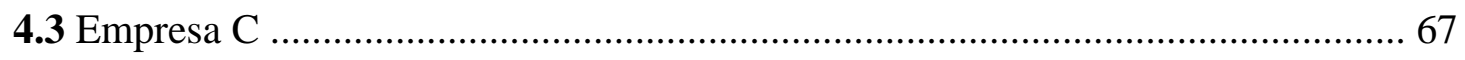

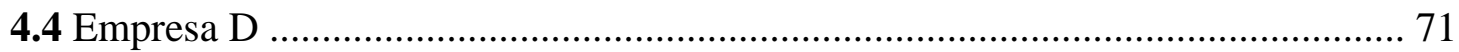

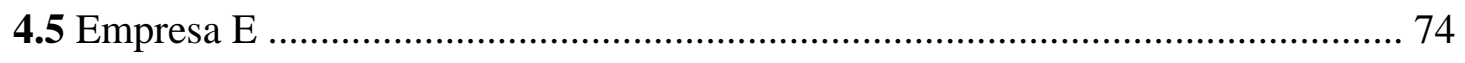

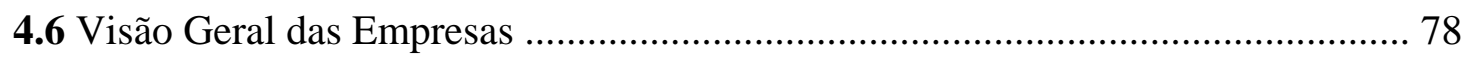

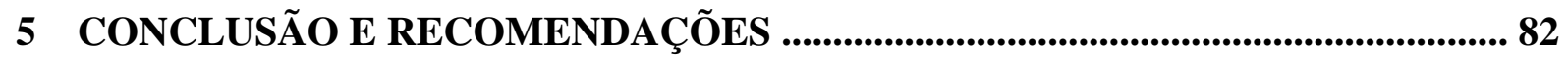

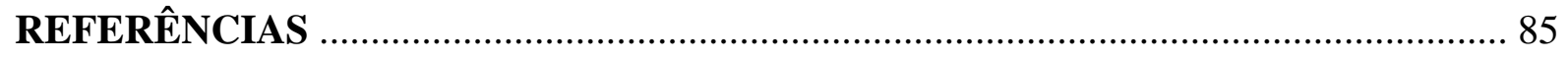

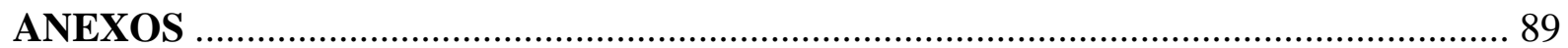




\section{LISTA DE SIGLAS}

BNDES - Banco Nacional de Desenvolvimento Econômico e Social 08

DRE - Demonstração do Resultado do Exercício 38

EBITDA - Earnings Before Interest, Tax, Depreciation and Amortization - Lucros antes dos juros, impostos, depreciação e amortização 40

EVA - Economic Added Value - Valor Econômico Adicionado 40

IPA - Índice de Preços por Atacado 07

FEBRAFARMA - Federação Brasileira da Indústria Farmacêutica 07

GRUPEMEF - Grupo dos Profissionais Executivos do Mercado Farmacêutico 11

IBGE - Instituto Brasileiro de Geografia e Estatística 09

RAIS - Relação Anual de Informações Sociais 07

SEBRAE - Serviço Brasileiro de Apoio às Micro e Pequenas Empresas 08

SECEX - Secretaria de Comércio Exterior 09 


\section{LISTA DE FIGURAS}

FIGURA 1 -Fundamentação Teórica do Estudo............................................................... 16

FIGURA 2 - Nível de Decisão e Tipos e Planejamento .................................................... 22

FIGURA 3 - O Processo de Planejamento Estratégico de Negócios ...................................... 24

FIGURA 4 - Visão Geral do Processo Orçamentário .......................................................... 32

FIGURA 5 - Processo Orçamentário: um exemplo da indústria farmacêutica ....................... 34

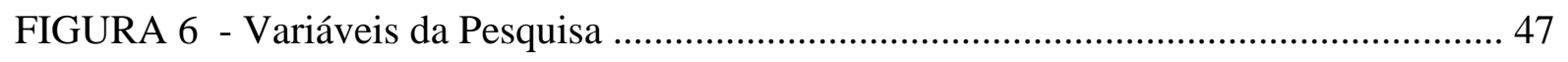




\section{LISTA DE TABELAS}

TABELA 1 - Critérios de Classificação de Empresas por Porte ........................................ 09

TABELA 2 - Escala para Avaliação do Processo Orçamentário ...................................... 56 


\section{LISTA DE GRÁFICOS}

GRÁFICO 1 - Indústrias Farmacêuticas no Brasil por Faturamento e Porte .......................... 12

GRÁFICO 2 - Quantidade de Indústrias Farmacêuticas no Brasil por Porte ......................... 12

GRÁFICO 3 - Avaliação do Processo Orçamentário - Empresa A ...................................... 62

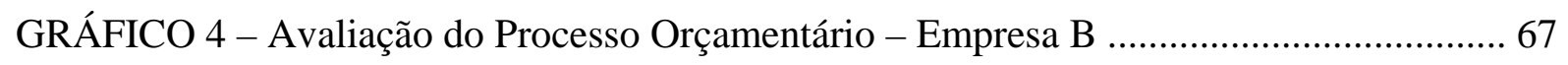

GRÁFICO 5 - Avaliação do Processo Orçamentário - Empresa C ...................................... 70

GRÁFICO 6 - Avaliação do Processo Orçamentário - Empresa D ...................................... 74

GRÁFICO 7 - Avaliação do Processo Orçamentário - Empresa E ...................................... 78

GRÁFICO 8 - Avaliação do Processo Orçamentário - Média por empresa ........................... 81

GRÁFICO 9 - Avaliação do Processo Orçamentário - Média Geral por item ...................... 81 


\section{INTRODUÇÃO}

A indústria farmacêutica tem uma função importante na vida humana e na economia do Brasil e do mundo.

Com o aumento da expectativa de vida do homem e a crescente busca por qualidade de vida, o mercado farmacêutico mundial cresce continuamente e permanece como um dos mais rentáveis e promissores.

O mercado mundial de produtos farmacêuticos alcançou US\$ 232 bilhões, em 2004. O Brasil participa com apenas 0,15\%, representado por cerca de 692 estabelecimentos produtores de medicamentos para uso humano, segundo a RAIS (Relação Anual de Informações Sociais) do mesmo período. A Febrafarma (Federação Brasileira da Indústria Farmacêutica) informou que o volume exportado pelo Brasil cresceu 3,4\% ao ano entre 2000 e 2005, mostrando que o potencial de crescimento é significativo, visto o tamanho do mercado e o pequeno crescimento atual.

É um setor marcado por intervenções governamentais no passado (tabelamento, administração e congelamento de preços) e está entre os mais regulados no presente. Estas intervenções certamente afetam a rentabilidade destas indústrias.

Se compararmos os reajustes de preços acumulados liberados entre 2001 e 2005, um total de 52,85\%, contra 82,81\%, registrados pelo IPA (Índice de Preço por Atacado) acumulado, é evidente a grande diferença entre os preços adotados e as reais necessidades desta indústria. Além disso, de acordo com o "Comparativo Internacional de Preços de Produtos Farmacêuticos em 2005”, da Febrafarma, o Brasil tem o quinto menor preço de medicamentos ao consumidor, desconsiderados os impostos, se comparado com 30 outros países listados neste relatório (ROMANO, PELAJO e SILVA, 2007) 
A gestão desses e outros problemas do setor, como a alta carga tributária, certamente exigiu e ainda exige muitas habilidades de seus administradores, bem como o uso de ferramentas de apoio para a tomada de decisão e para o controle gerencial.

\subsection{JUSTIFICATIVA DO TEMA}

A concorrência acirrada nos mercados nacional e internacional, as mudanças e a evolução nas necessidades dos consumidores, a pesada carga tributária e o alto custo do dinheiro são fatores que exigem mudanças no perfil das empresas e de seus administradores. O aperfeiçoamento das técnicas de gestão das finanças é uma dessas exigências.

Nesse moderno mercado globalizado, também estão insertas as empresas de médio porte, que vêm desempenhando crescente e importante papel no desenvolvimento econômico do país.

As empresas de médio porte podem ser diferenciadas das pequenas ou grandes empresas por dois critérios mais comuns de classificação: número de empregados (utilizado

pelo SEBRAE - Serviço Brasileiro de Apoio às Micro e Pequenas Empresas) e pelo faturamento bruto anual (utilizado pelo BNDES - Banco Nacional de Desenvolvimento Econômico e Social). Assim, empresas que possuem de 50 a 499 empregados ou com faturamento bruto anual entre $\mathrm{R} \$ 10,5$ milhões e $\mathrm{R} \$ 60$ milhões podem ser consideradas como médias empresas, conforme se apresenta na Tabela 1.

A importância desse grupo de empresas para o Brasil pode ser evidenciada na contribuição para a geração de empregos. Segundo a RAIS (Relação Anual de Informações Sociais) 2006, dos 35.155 empregados formais, cerca de 28\%, ou 9.660, trabalham nas empresas de médio porte. Outros 38\% trabalham em micro e pequenas e 34\% em grandes 
empresas. O percentual dos empregados alocados em micro, pequenas e médias empresas soma 66\%, demonstrando sua relevância para o país.

\begin{tabular}{|c|c|c|}
\hline Porte / Critério & Número de Empregados (SEBRAE) & Faturamento Bruto Anual (BNDES) \\
\hline \multirow[t]{2}{*}{ Microempresa } & até 09 (comércio e serviço) & \multirow[t]{2}{*}{ Até R\$ 1.200 mil } \\
\hline & até 19 (indústria) & \\
\hline \multirow[t]{2}{*}{ Pequena Empresa } & de 10 a 49 (comércio e serviço) & \multirow[t]{2}{*}{ Superior a $\mathrm{R} \$ 1.200$ até $\mathrm{R} \$ 10.500 \mathrm{mil}$} \\
\hline & de 20 a 99 (indústria) & \\
\hline \multirow[t]{2}{*}{ Média Empresa } & de 50 a 99 (comércio e serviço) & \multirow[t]{2}{*}{ Superior a $\mathrm{R} \$ 10.500 \mathrm{mil}$ até $\mathrm{R} \$ 60.500 \mathrm{mil}$} \\
\hline & de 100 a 499 (indústria) & \\
\hline \multirow[t]{2}{*}{ Grande Empresa } & acima de 100 (comércio e serviço) & \multirow[t]{2}{*}{ Superior a $\mathrm{R} \$ 60.500 \mathrm{mil}$} \\
\hline & acima de 500 (indústria) & \\
\hline
\end{tabular}

Fonte: SEBRAE e BNDES

Na indústria brasileira, por exemplo, estas empresas respondem por cerca de $30 \%$ da riqueza gerada, segundo dados de 2005 da “Pesquisa Industrial Anual”, realizada pelo IBGE (Instituto Brasileiro de Geografia e Estatística). Além disso, a SECEX (Secretaria de Comércio Exterior) divulgou, em 2006, que 74\% do total de empresas exportadoras do país são micro, pequenas e médias empresas.

Um estudo, divulgado em 2007 pela empresa de consultoria Deloitte (disponível em:

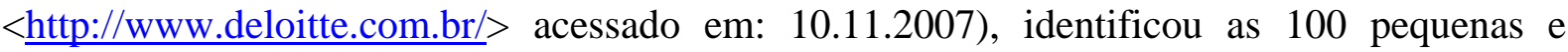
médias empresas brasileiras que mais cresceram em 2004-2006. Para 41\% dessas organizações, a adoção de um modelo profissional de gestão será um dos principais fatores impulsionadores do crescimento, nos próximos 3 a 5 anos e $63 \%$ consideram que o investimento na estrutura de gestão, incluindo gerência geral, planejamento, finanças, contabilidade etc., é um dos fatores que vão garantir a competitividade em curto prazo.

Essas pesquisas corroboram as afirmações de Welsch (1983, p. 19), Figueiredo e Caggiano (2004, p. 27) e Frezatti (2006, p. 10) de que um dos enfoques mais importantes 
utilizados para facilitar a execução eficaz do processo de gestão compreende o planejamento e controle de resultados, incluindo a elaboração de orçamentos para auxiliar na administração.

Assim, a idéia é que o orçamento empresarial, que é parte de um processo de planejamento de longo prazo, possa auxiliar o gestor no exercício de suas funções administrativas.

Se for observada a estrutura organizacional de uma empresa de grande porte, há grande possibilidade de serem encontrados gestores empenhados na elaboração de planejamentos estratégicos e orçamentos anuais que vão apoiar as suas decisões gerenciais, visando ao cumprimento dos objetivos empresariais. Provavelmente, eles terão à sua disposição sistemas computadorizados para registro das informações contábeis, possibilitando a apuração e controle dos resultados, bem como o seu reporting mensal aos acionistas e investidores.

No caso das micro e pequenas empresas, pesquisas demonstram que isso nem sempre ocorre. O proprietário utiliza quase todo o seu tempo e esforço em atividades operacionais, sem dar a importância devida à elaboração de planos gerenciais e financeiros. (BEDÊ, 2005)

Enquanto as grandes empresas estão se desenvolvendo cada vez mais e as pequenas, por sua vez, ainda estão em busca de um espaço, as empresas de médio porte estão exatamente no meio. Elas ainda não são grandes para utilizarem processos sofisticados, e muitas vezes caros, mas já não podem negar a necessidade de eficientes processos de gestão.

Para garantir a sobrevivência dessas empresas nessa fase em que a complexidade das atividades cresce, é imprescindível a adoção de processos mais eficientes.

Um desses processos seria a utilização de uma estrutura sistemática e abrangente para auxiliar na tomada de decisões, o que permitiria alcance dos objetivos. (YOO, 2007) 
Surgem algumas dúvidas com relação às empresas de médio porte: elas utilizam ferramentas para auxiliar a tomada de decisão e o controle gerencial? O orçamento empresarial é considerado por elas uma dessas ferramentas?

Com relação à abrangência, neste estudo tem-se a intenção de pesquisar as indústrias farmacêuticas em operação no Brasil, considerando sua importante função na economia mundial e também na vida humana.

Ao escolher esse setor para a realização do estudo, também foi levada em consideração a experiência profissional da autora em planejamento e controle financeiro numa multinacional de grande porte, do mesmo setor. Ademais, a bibliografia consultada normalmente aborda sistemas administrativos adotados pelas empresas de grande porte. Por tal motivo, a escolha do tema recaiu sobre uso do orçamento como ferramenta de apoio em empresas de médio porte.

Este estudo será realizado nas indústrias farmacêuticas classificadas como de médio porte, já que nessas organizações o processo administrativo é mais complexo em comparação às de pequeno porte. $\mathrm{O}$ foco nas médias indústrias desse setor também foi motivado pela escassez de estudos voltados especificamente para esse grupo de empresas, que merece ser estudado separadamente, pois, apesar de não necessitarem das complexas estruturas organizacionais adotadas pelas indústrias de grande porte, não devem ser administradas com a mesma simplicidade adotada pelas pequenas empresas.

O GRUPEMEF (Grupo dos Profissionais Executivos do Mercado Farmacêutico) classificou, em seu relatório “Ranking de Laboratórios” de julho de 2007 (Ver Anexo I), as 200 indústrias de acordo com o faturamento bruto anual. Entre abril/2006 e maio/2007, elas faturaram juntas cerca R\$ 24,3 bilhões. Desse valor, apenas R\$ 1,1 bi, ou 5\%, foi faturado pelas indústrias de médio porte e $\mathrm{R} \$ 0,3 \mathrm{bi}$, ou 1\%, pelas micro e pequenas. A grande parcela 
do faturamento foi abocanhada pelas grandes indústrias: as maiores (94\%) são representadas por multinacionais, somando R\$22,9 bilhões. Ver Gráfico 1.

Este faturamento foi captado nos pontos de vendas pelo IMS Health, empresa que fornece informações de inteligência de mercado para o setor farmacêutico.

\section{Gráfico 1 - Indústrias Farmacêuticas no Brasil por Faturamento e Porte}

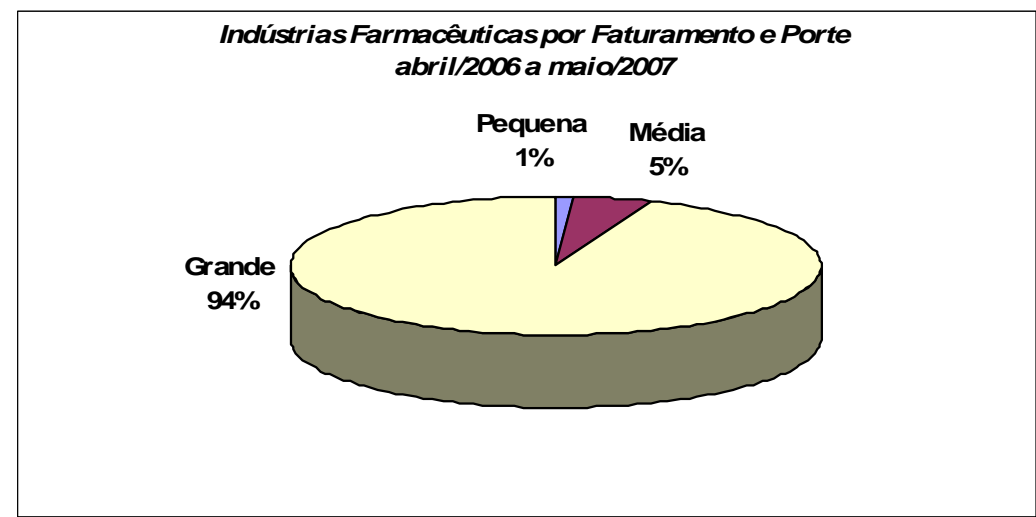

Fonte: GRUPEMEF. Relatório “Ranking de Laboratórios” dos 200 maiores, abril/2006 a maio/2007.

No Gráfico 2 apresenta-se a quantidade (por porte) das 200 maiores indústrias farmacêuticas, e por faturamento bruto mensal, conforme critério adotado pelo BNDES (Banco Nacional de Desenvolvimento Econômico e Social).

Gráfico 2 - Quantidade de Indústrias Farmacêuticas no Brasil por Porte

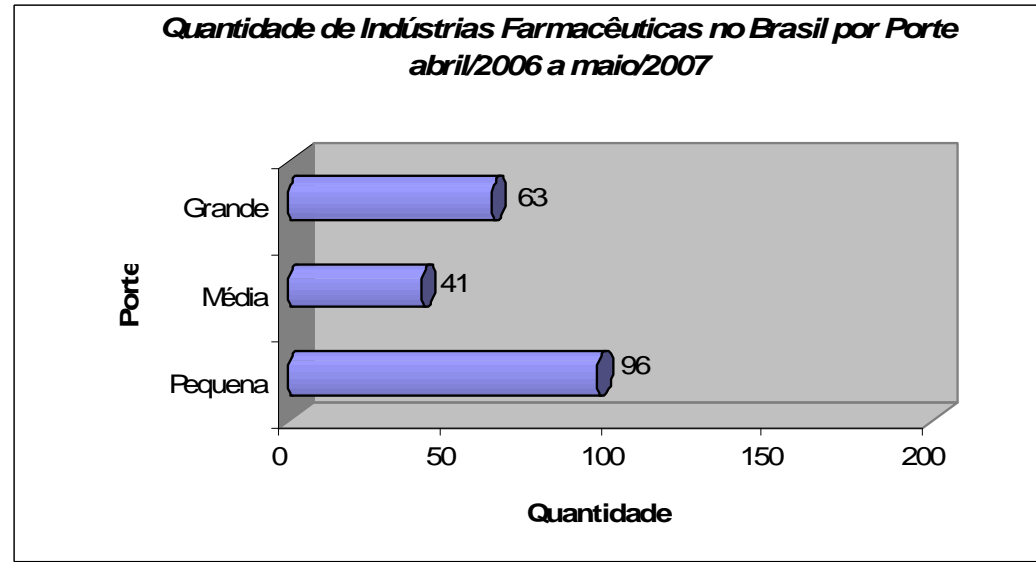


Fonte: GRUPEMEF. Relatório “Ranking de Laboratórios” dos 200 maiores, abril/2006 a maio/2007

A análise dos Gráficos 1 e 2 mostra que, apesar de as pequenas e médias indústrias representarem a maioria (137 indústrias), 94\% do faturamento estão concentrados nas indústrias de grande porte que, normalmente, possuem uma estrutura de gestão bem definida, incluindo um processo de planejamento formalizado, visando à consecução dos objetivos empresariais.

\subsection{DEFINIÇÃO DO PROBLEMA}

Devido à escassez de publicações sobre a utilização do orçamento em indústrias farmacêuticas de médio porte, indaga-se sobre a metodologia de planejamento e ferramentas de apoio à tomada de decisão.

A questão central está em: se essas empresas possuem ou não um orçamento estruturado e que seja utilizado pelos administradores e se esse pode ser utilizado como ferramenta de apoio à tomada de decisão e ao controle gerencial.

\subsection{OBJETIVO DO ESTUDO}

Em função do que se apresentou na justificativa e na definição do problema a ser pesquisado, o objetivo deste estudo é o de verificar se o orçamento empresarial é utilizado pelas indústrias farmacêuticas de médio porte e se é considerado uma ferramenta de apoio à tomada de decisões e ao controle gerencial.

Mais especificamente, pretende-se responder às seguintes questões: 
a) essas indústrias possuem um sistema de informações contábil-gerenciais adequado à necessidade dos gestores?

b) elas adotam uma estrutura formal para planejamento dos resultados em curto e longo prazos?

c) como é o modelo aplicado na elaboração do orçamento empresarial?

d) o processo orçamentário adotado é adequado às necessidades?

Neste estudo não se tem a intenção de verificar se a utilização do orçamento empresarial contribui para o sucesso ou não das empresas pesquisadas. Neste caso, outros assuntos devem ser levados em consideração além do orçamento empresarial.

Um resultado satisfatório deste estudo motivará novas aplicações do conceito de Orçamento Empresarial, assim como estudos mais profundos ou mesmo casos de aplicações práticas. 


\section{REVISÃO TEÓRICA}

A fundamentação teórica deste estudo é formada pelos seguintes conceitos:

- Sistema de informações gerenciais apoiando a tomada de decisões;

- Planejamento estratégico;

- Orçamento empresarial e

- Controle gerencial.

O ponto de partida para a revisão teórica é a importância do cumprimento dos objetivos empresariais por parte dos administradores. Esses gestores são chamados a decidir sobre as metas para alcançar os objetivos e elaborar planos (estratégicos e orçamentários) sobre como as metas serão atingidas, cuja finalidade deveria ser a garantia do aumento da riqueza dos investidores e, conseqüentemente, da continuidade da empresa.

Após a execução, é necessário também que haja controle gerencial para se verificar se as decisões tomadas foram cumpridas e, assim, podem levar a se tomarem novas decisões. (ANTHONY e GOVINDARAJAN, 2001, p. 34).

Para auxiliar o processo de tomada de decisões, os gestores necessitam de um sistema que disponibilize informações gerenciais em tempo, incluindo contabilidade, custos e orçamento (FIGUEIREDO e CAGGIANO, 2004, p. 36).

Neste contexto, surge a necessidade da elaboração do orçamento empresarial, como parte integrante do sistema de informação contábil-gerencial, que poderia atuar como uma ferramenta de apoio à tomada de decisões e ao controle gerencial.

Na Figura 1 demonstra-se, esquematicamente, essa fundamentação teórica: 


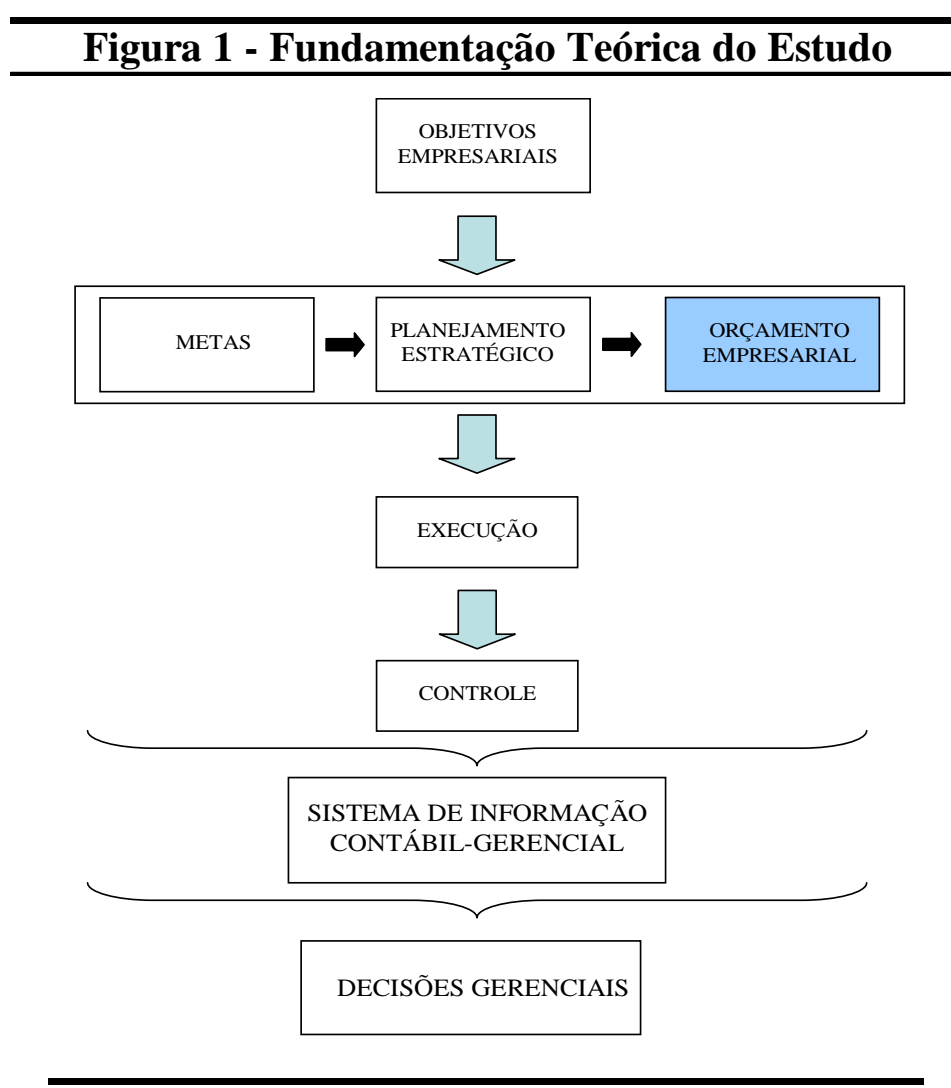

Fonte: A autora

\subsection{SISTEMA DE INFORMAÇÃO CONTÁBIL-GERENCIAL: APOIO ÀS DECISÕES GERENCIAIS}

\subsubsection{Decisões Gerenciais}

A competição globalizada tem exigido das empresas atitudes dinâmicas e eficazes na medida em que estas necessitam adaptar-se rapidamente às exigências do ambiente externo, para que possam continuar nos mercados atuais e também conquistar novos nichos.

A cada momento os gestores são chamados a tomar decisões que conduzam a ações que vão levar ao cumprimento dos objetivos estabelecidos pelos proprietários ou acionistas das empresas. 
Com o aumento do volume de dados e variáveis, os sistemas de informações gerenciais vêm sendo cada vez mais solicitados para o fornecimento de informações, para que as decisões sejam tomadas com a rapidez exigida pelo mundo empresarial.

A definição de um sistema de gestão pode possibilitar a obtenção dessas informações de forma ágil e eficiente. O objetivo desse sistema deve ser o de processar dados de cinco funções principais: planejamento, organização, controle, comunicação e motivação. (FIGUEIREDO E CAGGIANO, 2004, p.43).

No planejamento, as decisões são simuladas antecipadamente incluindo-se previsões explícitas a respeito das condições futuras em que as empresas atuarão na busca de seus objetivos, inclusive o lucro. (TUNG, 1994, p.31)

A organização supõe a definição de uma estrutura administrativa que vai implementar as ações planejadas. O controle dá-se por meio da confrontação entre os valores realizados e os valores planejados, verificando se as ações foram eficazes e orientando novas decisões.

A circulação de informações entre as áreas da empresa e entre esta e o ambiente externo é o papel da comunicação. Essas informações interpretadas corretamente pelos gestores devem promover resultados positivos. Dessa forma, a motivação tem importante papel: fazer com que os objetivos da organização sejam coincidentes com os objetivos das áreas, estabelecidos pelos seus colaboradores.

Nesse contexto, admite-se que não só o planejamento, como também as previsões mais explícitas, ou orçamentos, devem fazer parte do sistema de informações gerenciais da empresa. 


\subsubsection{Sistema de Informações Gerenciais}

A invasão de softwares e hardwares, capazes de processar milhões de informações em segundos, proporcionou aos gestores acesso a uma grande quantidade de informações, que podem ser utilizadas para orientar suas decisões.

É consenso geral no mundo corporativo que as informações são um dos ativos mais valiosos de uma empresa, e que a empresa detentora de bons sistemas de informações tende a ser mais dinâmica, mais atuante e mais agressiva do que seus concorrentes. (CASSARRO, 2003, p. 26)

O acúmulo de informações desnecessárias pode causar desperdício de tempo e de dinheiro. Para evitá-lo, a empresa deve contar com pessoal, tanto da alta quanto da média administração, com capacidade e motivação para utilizar essas informações para melhores decisões.

SCHWARTZ (apud OLIVEIRA, 2007, p.25) define o sistema de informações gerenciais como um sistema que envolve pessoas, equipamentos, procedimentos, documentos e comunicações que coleta, valida, executa operações, transforma, armazena, recupera e apresenta dados para uso no planejamento orçamentário, contabilidade, controle e em outros processos gerenciais para os vários propósitos administrativos. Além de processamento de dados, eles podem fornecer informações relevantes para a tomada de decisões gerenciais.

Para esse autor, os principais sistemas de uma empresa vão processar dados e prover informações relativas às seguintes áreas: produção, materiais, marketing, finanças, recursos humanos, serviços e gestão empresarial.

A controladoria é o órgão administrativo cuja função consiste em dar suporte à gestão empresarial. Para tanto realiza também atividades de planejamento, controle e contabilidade. Seu principal objetivo é o de garantir informações adequadas ao processo decisório; para tanto 
deve possuir um sistema de informação contábil-gerencial que permita o compartilhamento de informações sobre o orçamento, custos e contabilidade. As demais áreas (comercial, industrial, suprimentos, recursos humanos, financeira) deverão repassar as informações financeiras para esse sistema. (FIGUEIREDO e CAGGIANO, 2004, p.27)

Esses mesmos autores defendem que, para serem eficientes, essas informações deverão estar interligadas por uma base-padrão, o que vai proporcionar consistência e agilidade na apuração do resultado operacional e na elaboração do orçamento empresarial.

Assim, a opção por sistemas de informações interligados é recomendada. No entanto deve ser analisado o custo-benefício, levando-se em consideração o custo do sistema (hardware, software, licença, manutenção etc.) e o benefício gerado por ele.

O sistema integrado de informações, também conhecido como ERP (Enterprise Resource Planning), é composto por sistemas para armazenar, processar e organizar as informações geradas por todos os processos da empresa.

A pesquisa realizada pela consultoria Deloitte, sobre as pequenas e médias empresas que mais crescem no Brasil (disponível em: <http://www.deloitte.com.br/>, acessado em: 10.11.2007), mostra que 47\% delas investiram num sistema integrado de informações, nos últimos 3 anos, e que outros 38\% pretendem investir nele nos próximos 3 a 5 anos.

O sistema de informação gerencial pode apresentar alguns benefícios, segundo OLIVEIRA (2005, p. 31), como:

- redução dos custos operacionais;

- acesso mais rápido às informações, proporcionando relatórios mais rápidos e precisos;

- $\quad$ tomada de decisões mais rápidas e precisas; 
- maior interação entre os tomadores de decisão, devido à facilidade no fluxo de informações;

- fornecimento de melhores projeções e simulações;

- funcionários mais motivados, entre outros.

O gestor, porém, deve estar atento para alguns pontos que podem levar o sistema ao fracasso (ACKOFF, 1984, p.79):

- o executivo não necessita de muitas informações relevantes;

- o executivo não precisa de todas as informações que deseja;

- o gerente pode não tomar boas decisões, mesmo que as informações lhe tenham sido entregues em tempo;

- mais comunicação, ou mais informação, não significam desempenho melhor; entre outras

Portanto, após a revisão teórica desse item, pode-se considerar que um sistema de informação contábil-gerencial bem estruturado pode auxiliar o gestor na tomada de decisões, visto que proporciona maior consistência e agilidade na obtenção das informações e preparação dos relatórios, inclusive na elaboração do orçamento empresarial e no controle gerencial. No entanto devem ser observadas suas vantagens e limitações.

\subsection{PLANEJAMENTO ESTRATÉGICO}

Antes de iniciar a abordagem do planejamento estratégico, são necessárias algumas considerações sobre a função do planejamento empresarial. 


\subsubsection{O Planejamento nas Empresas}

Após a definição dos objetivos empresariais pelos investidores e da definição das metas para se alcançarem os objetivos por parte da alta-diretoria da empresa, o próximo passo é a elaboração do planejamento de como as metas serão atingidas.

O planejamento foi conceituado por ACKOFF et al. (1984, p.2) como a "definição de um futuro desejado e de meios eficazes para alcançá-lo”.

Nesse sentido, o planejamento deve ser visto como um processo contínuo que levará os gestores a indagações sobre o que fazer, como, quando, quanto, para quem e onde. Esses questionamentos vão promover o estabelecimento de formas para se atingirem os objetivos empresariais.

OLIVEIRA (2005, p. 45) classificou o planejamento em tipos: estratégico, tático e operacional. Eles são corroborados por FISCHMANN e ALMEIDA (1991, p. 25).

O planejamento estratégico visa estabelecer a direção que a empresa deve seguir. São eleitas estratégias e ações para se alcançarem os objetivos de longo e curto prazos. É um planejamento predominantemente qualitativo.

O planejamento tático está relacionado com a definição de objetivos de curto prazo, normalmente um ano, envolvendo decisões administrativas. É predominantemente quantitativo. O orçamento empresarial é um tipo de planejamento tático. O planejamento de longo prazo é uma extrapolação do planejamento tático para períodos superiores a dois anos.

Os planejamentos operacionais são formalizados por meio de documentos escritos, basicamente planos de ação ou planos operacionais. Equivalem ao conjunto de partes homogêneas do planejamento tático. Devem informar: os recursos necessários para sua implementação, os procedimentos a serem adotados, os resultados esperados e os responsáveis por sua execução. 
No topo da pirâmide, exibida na Figura 2, está o nível estratégico, ocupado pela alta gestão, responsável pelo planejamento estratégico e pelas decisões estratégicas. As decisões tomadas nesse nível vão afetar toda a empresa.

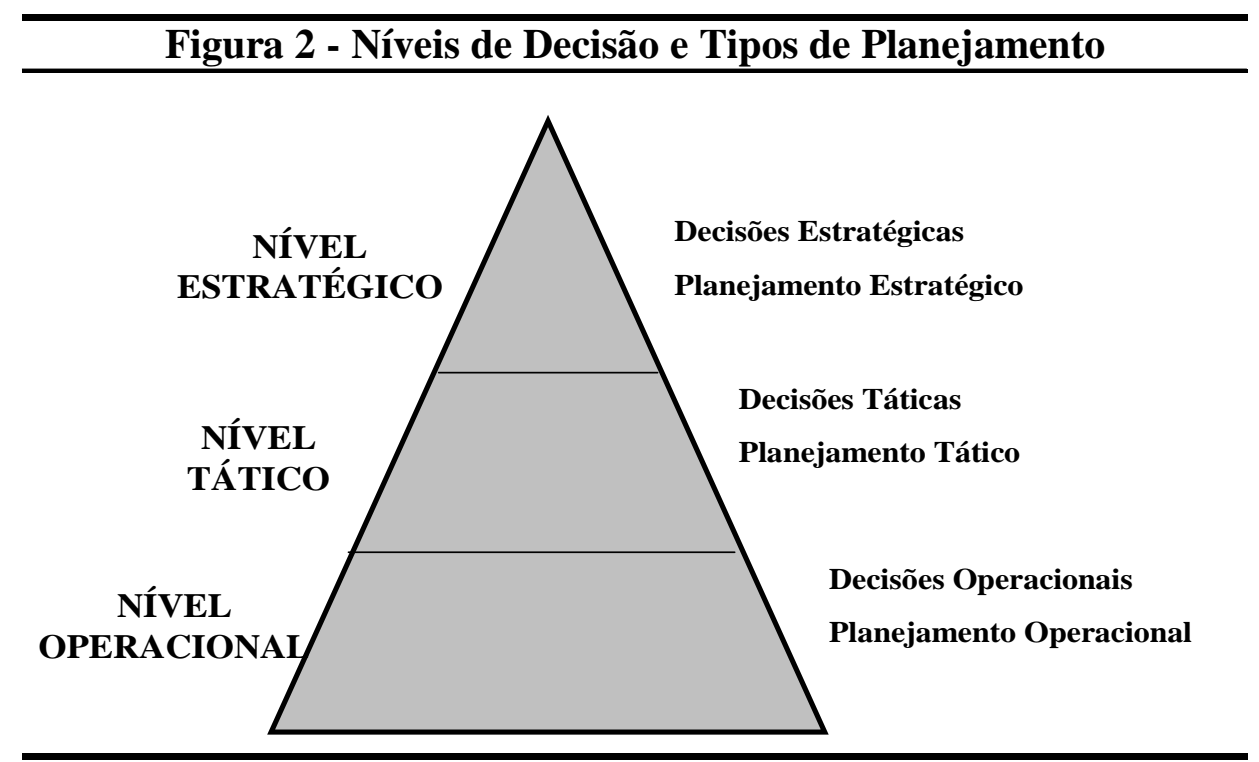

Fonte: Adaptado de OLIVEIRA, D. P. R. de. Planejamento Estratégico : conceitos, metodologia e práticas. 22. ed. São Paulo: Atlas, 2005, p. 45

No nível tático, estão os gestores responsáveis pelo planejamento tático, ou de curto prazo. Eles têm a função de utilizar os recursos disponíveis de forma eficiente, para a consecução dos objetivos previamente fixados. As decisões tomadas nesse nível afetam somente parte da empresa.

Os gestores que fazem parte do nível operacional, na base da pirâmide, cuidam das decisões operacionais e do planejamento operacional. O foco básico está nas atividades diárias da empresa. Neste estudo não será abordado esse nível de planejamento. 


\subsubsection{O Planejamento Estratégico}

A origem da palavra estratégia vem do grego “estrategos”, os comandantes que faziam o planejamento das guerras na Grécia antiga. Estratégia era a palavra utilizada para representar a "arte dos generais" para vencerem a guerra. Com o passar dos anos, essa palavra passou a ser utilizada no mundo empresarial, representando os meios para se conduzirem os negócios e enfrentar a concorrência.

A estratégia pode ser conceituada como a decisão sobre quais recursos devem ser adquiridos e usados visando aproveitar as oportunidades e minimizar as incertezas. Sua função é a mobilização desses recursos para atingir os objetivos de longo prazo e o seu objetivo é o de "permitir maior flexibilidade de resposta às contingências imprevisíveis" (MICHEL e LODI, apud CAMARGO E DIAS, 2003, p. 29)

Um plano estratégico eficaz deve contemplar uma definição clara do negócio e como ele vai funcionar no longo prazo. Com base nesse plano, deve ser traçado um outro, de curto prazo, com os principais objetivos e metas. A definição das metas, ou das formas como os objetivos serão atingidos, poderá facilitar o acompanhamento de sua execução e permite o cumprimento dos objetivos gerais da empresa. (AXSON, 2003, p. 85)

Os modelos de planejamento estratégico apresentados por FISCHMANN e ALMEIDA (1991, p. 33), por OLIVEIRA (2005, p. 81) e por KOTLER (2000, p. 98) possuem estruturas bastante semelhantes. Os modelos de Fischmann, Martinho e Kotler podem ser divididos em três principais etapas: planejamento, implementação e acompanhamento. O modelo sugerido por Oliveira apresenta somente a etapa de planejamento, apesar de fazê-lo mais detalhadamente. 
Na Figura 3 apresentam-se as oito etapas sugeridas por Kotler para um planejamento estratégico.

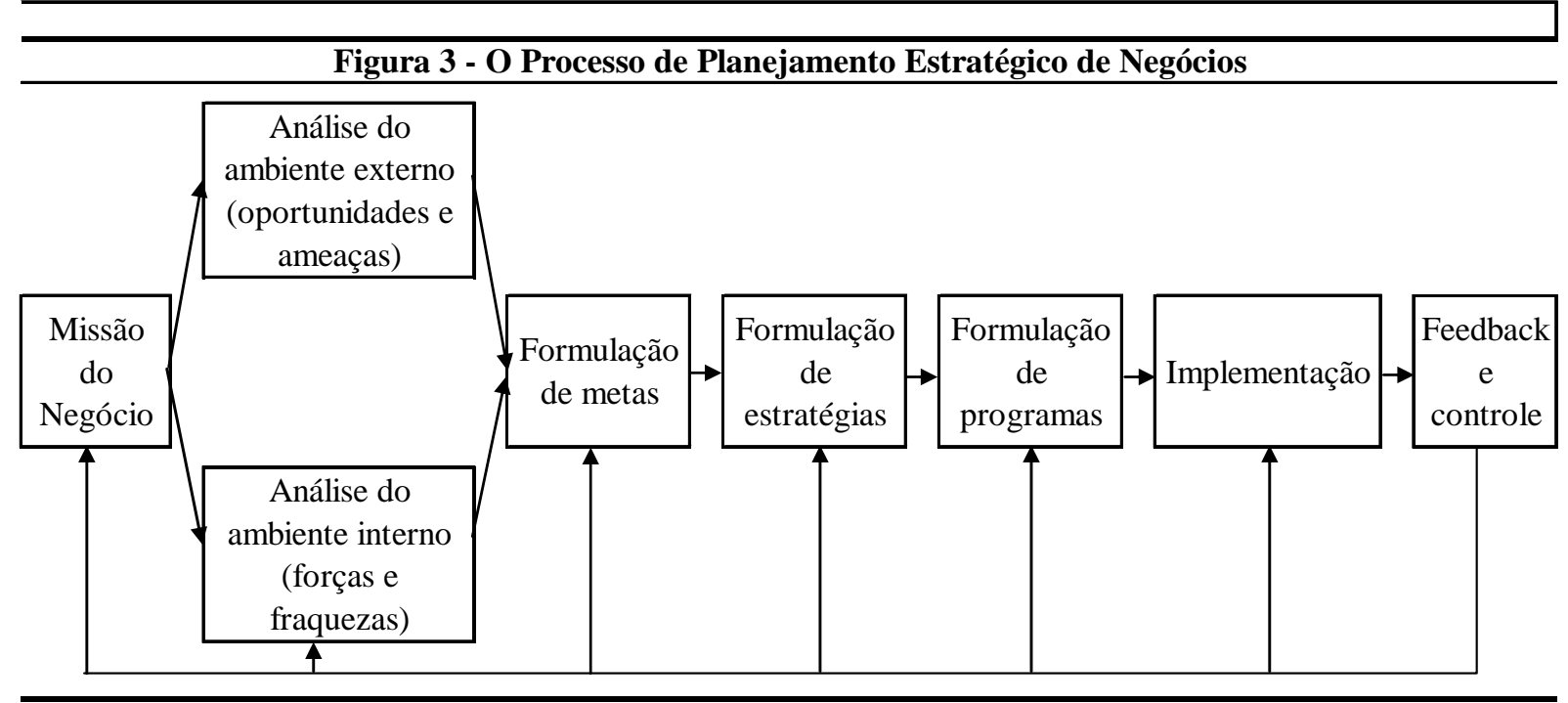

Fonte: KOTLER, Philip. Administração de marketing: a edição do novo milênio. Tradução de Bazán Tecnologia e Linguística. São Paulo: Prentice Hall, 2000, p. 98

O processo tem início com a definição da missão do negócio, ou seja, a determinação do porquê da existência da empresa.

Definida a missão, parte-se para a análise das oportunidades e ameaças, causadas pelo ambiente externo, que poderão afetar a empresa no período para o qual o planejamento está sendo elaborado. Nesta fase também é necessária a avaliação das forças e fraquezas internas. Pode ser utilizada a Análise Swot (dos termos em inglês strengths, weaknesses, opportunities, threats), ou as Matrizes de Oportunidades e Ameaças.

A terceira etapa considera a formulação das metas, que são objetivos em termos de magnitude e prazo. A quarta refere-se à formulação de estratégias, que trata da maneira de alcançar as metas traçadas.

A formulação de programas, ou orçamento, na etapa seguinte, diz respeito à definição detalhada das atividades de apoio e também à estimativa de seus custos. A penúltima fase desse modelo é a implementação da estratégia por meio da execução das atividades programadas. 
A última fase do processo, mas não menos importante, é o feedback e controle. Nesta etapa é realizado o acompanhamento dos resultados, com o objetivo de verificar se a estratégia adotada está sendo eficaz. O gestor deve observar atentamente os acontecimentos nos ambientes interno e externo, e analisar se há necessidade de efetuar alguma revisão ou alteração no que foi planejado.

Em empresas de grande porte, esse é um processo formal, que faz parte de um planejamento de longo prazo, revisto anualmente, primeiro na matriz e depois nas unidades, com a participação da alta administração e executivos de planejamento. Após aprovado, o plano será refletido no planejamento tático, ou seja, no orçamento empresarial, para implementação no ano seguinte.

De acordo com Pearce (2004), as empresas de menor porte poderão adotar o mesmo processo de planejamento de negócios, listando e analisando os produtos que serão lançados, a concorrência, os fornecedores, as políticas gerenciais e de marketing a serem adotadas pela empresa, as necessidades de investimento e caixa para implementação do plano.

OLIVEIRA (2005, p.282-286) apresenta algumas vantagens e outras limitações do planejamento estratégico.

Segundo esse autor, o planejamento estratégico, quando elaborado e utilizado adequadamente pela empresa, poderá proporcionar: facilidade e agilidade no processo de tomada de decisão; orientação ao desenvolvimento de outros planejamentos táticos e operacionais; fortalecimento e agilidade ao processo orçamentário; possibilidade de obtenção de melhores resultados operacionais, entre outras vantagens.

No entanto, alguns pontos podem causar falhas no planejamento estratégico. Dentre eles, vale destacar: a falta de estrutura adequada do setor; a não consideração da realidade da 
empresa; não-envolvimento dos níveis hierárquicos; planejamento não levado a sério; controle e avaliação inadequados, entre outros.

Outra limitação a ser destacada, na opinião de ANTHONY e GOVINDARAJAN (2001, p. 387), seria a elaboração de um processo formal de planejamento estratégico por empresas de menor porte que não utilizam o planejamento como forma apoio à gestão. Neste caso, o plano não faria sentido, visto que as suas projeções para o futuro não são confiáveis.

Assim, da mesma forma que um planejamento estratégico bem elaborado pode fortalecer e agilizar o processo orçamentário, as falhas ou a não realização poderão comprometer a sua elaboração ou implementação, e o conseqüente alcance dos objetivos empresariais.

\subsection{ORÇAMENTO EMPRESARIAL}

Foi visto, no item anterior, é por meio do planejamento estratégico que a empresa deve escolher a direção que vai seguir para alcançar seus objetivos de longo prazo. Definidas as estratégias de longo prazo, o próximo passo é a elaboração do plano anual de marketing, que vai ser a base para o orçamento empresarial, ou planejamento de curto prazo.

O orçamento empresarial é um produto do planejamento estratégico que atuará como alerta aos gestores, indicando se o plano é eficaz. É um plano financeiro e cronológico, normalmente para um ano, que visa implementar a estratégia escolhida. (FREZATTI, 2006, p.44)

Assim, por meio do orçamento, os gestores podem organizar e implementar eficazmente os recursos organizacionais. (ATHAR, in Handbook of Budget, P. 1.4) 
Os objetivos do orçamento estão ligados ao planejamento, à coordenação e ao controle das atividades e resultados monetários. Abaixo, estão listadas algumas de suas pretensões: (FIGUEIREDO E CAGGIANO, 2004, p. 36)

- orientar a execução das atividades;

- possibilitar a coordenação dos esforços de uma área específica e de toda a empresa;

- otimizar o resultado global da empresa;

- reduzir os gastos operacionais;

- facilitar a identificação das variações entre o que foi orçado e o realizado, o que permite implementar ações corretivas.

\subsubsection{Os Princípios Gerais de Planejamento}

Segundo FREZATTI (2006, p.45), os princípios clássicos apresentados por WELSCH (1983, p.50) "levam em conta a estrutura necessária e servem de checklist para o adequado desenvolvimento do orçamento”.

Assim, a empresa que atentar para tais princípios poderá gerar melhores informações para serem utilizadas no processo de tomada de decisões e controle gerencial.

São dez os princípios gerais de planejamento:

a. envolvimento administrativo - é fundamental para a eficiência do processo orçamentário. Toda a administração, principalmente os níveis mais altos, deve estar convencida da importância do planejamento, devendo apoiar, orientar e participar da sua execução; 
b. adaptação organizacional - a formalização da estrutura organizacional é importante para que as funções e as responsabilidades de cada área estejam claramente definidas e acordadas com seus gestores;

c. contabilidade por área de responsabilidade - consiste no lançamento dos fatos contábeis por unidade de negócio, centros de lucros e/ou centros de custos. Dessa maneira será possível a apuração de resultados por responsabilidade;

d. orientação para objetivos - é importante que os objetivos de cada área de resultado e do seu gestor estejam em sintonia com as metas gerais da empresa, permitindo coerência entre as ações, evitando dúvidas no seu entendimento e cumprimento;

e. comunicação integral - o planejamento deverá ser comunicado a todos os gestores responsáveis pela sua execução. Quanto mais transparente for a comunicação, maiores serão as possibilidades de a empresa alcançar o resultado previsto. A empresa deverá contar com sistema de informática adequado às suas necessidades.

f. expectativas realistas - os valores previstos no plano devem expressar a realidade. Tanto as projeções muito agressivas quanto as muito conservadoras devem ser evitadas;

g. oportunidade - as informações do planejamento devem estar disponíveis antes do início de sua execução. É salutar a elaboração de um cronograma que detalhe as atividades, datas e responsáveis por ação, cada uma delas referente a esse processo;

h. aplicação flexível - uma vez elaborado e aprovado, o planejamento deverá ser seguido por toda a empresa. Deve, porém, refletir a realidade e ser compatível 
com as necessidades dos ambientes (interno e externo). Assim, deverá ser flexível para que alterações possam ser feitas;

i. reconhecimento do esforço individual e do grupo - o sucesso do processo de planejamento também está ligado ao nível de motivação dos indivíduos e grupos envolvidos. A organização deverá incluir na avaliação de desempenho itens relativos ao cumprimento ou não do planejamento, proporcionando conseqüências na remuneração variável;

j. acompanhamento - para que o planejamento seja eficaz, é primordial que haja o monitoramento, acompanhamento e controle, visando identificar variações entre os valores previstos e realizados. O controle poderá indicar necessidade de ações corretivas e/ou revisões no planejamento.

A verificação da observância dos princípios deve ocorrer antes do início do planejamento, permitindo eventuais correções na estrutura organizacional e a redução de falhas no processo.

\subsubsection{A Organização do Orçamento}

Nas grandes corporações, o processo orçamentário é realizado por uma comissão orçamentária, liderada por membros da gerência de planejamento e controle financeiro, que normalmente está subordinada ao diretor de controladoria, incluindo também membros das áreas de vendas, marketing e produção.

Fica sob a responsabilidade da área de planejamento a divulgação das instruções para a elaboração do orçamento e do cronograma das atividades, a coleta e consolidação dos valores informados pelas áreas, a elaboração dos relatórios finais projetados, a análise dos 
valores finais projetados para reporting ao diretor da controladoria. Esse diretor apresenta os números para a presidência e demais diretorias.

Conforme salientado nos princípios, para que o orçamento empresarial seja adequado, é necessária a participação efetiva dos gestores de todas as áreas funcionais, e de todos os níveis hierárquicos. Cada um desses gestores deve ser informado a respeito das metas financeiras pelas quais é responsável, devendo garantir o seu cumprimento. Para que isso seja possível, o orçamento deve ser elaborado por área, ou centros de responsabilidade, consolidado por área funcional, por unidades de negócios e, finalmente, para a consolidação total da empresa (CORR \& HILL, in Corporate Controller’s Manual, 1988, p. DI-3).

\subsubsection{Etapas do Processo Orçamentário}

Para que o processo orçamentário seja eficaz, deve estar apoiado num sistema de informações gerenciais consistente, bem estruturado e ágil, conforme foi discutido no Capítulo 2, item 1. O sistema orçamentário deve ser parte integrante do sistema de informações contábeis e gerenciais a serem utilizadas para a tomada de decisões.

O sistema orçamentário pode ser entendido como o conjunto de vários orçamentos parciais interligados. Serve-se de técnicas e procedimentos contábeis aplicados antecipadamente aos fatos decorrentes de planos, políticas e metas para a obtenção de um resultado desejado. Ao final do processo são obtidos os demonstrativos financeiros preparados com base nessas expectativas. (MOREIRA, J.C., 2002, p. 15)

Como todos os sistemas, ele também recebe dados (entradas) e transforma-os em informações (saídas). Nele são executados diferentes processos como coleta de dados, registro, consolidação, análise e gerenciamento visando à emissão de informações, como: relatórios financeiros, orçamentos, tabelas, gráficos etc. 
Além das informações do próprio orçamento (dados planejados), também compõem o sistema de orçamento as informações registradas pela contabilidade (financeira e custos). A contabilidade de custos fornece informações para estimativa do custo dos produtos e informações históricas para comparação. A financeira informa os fatos contábeis realizados. Ambas as informações serão necessárias para o controle gerencial, que será abordado no próximo capítulo.

A Figura 4 apresenta uma visão geral do processo orçamentário, em uma adaptação dos modelos sugeridos por WELSCH (1983, p.93) e FREZATTI (2006, p.46). FIGUEIREDO e CAGGIANO (2004, p.122) também apresenta uma visão bastante similar.

Antes do início da elaboração do orçamento empresarial, devem estar definidos os objetivos e metas empresariais, bem como as estratégias para o seu alcance.

O passo inicial do processo orçamentário é a determinação de premissas financeiras e operacionais como: capacidade produtiva, condições mercadológicas, disponibilidade de caixa, taxa de câmbio a ser utilizada, taxa de inflação, percentuais de ajustes de salários, contratos e preço de venda etc. Após essas definições, inicia-se efetivamente a elaboração do orçamento. 
Figura 4 - Visão Geral do Processo Orçamentário

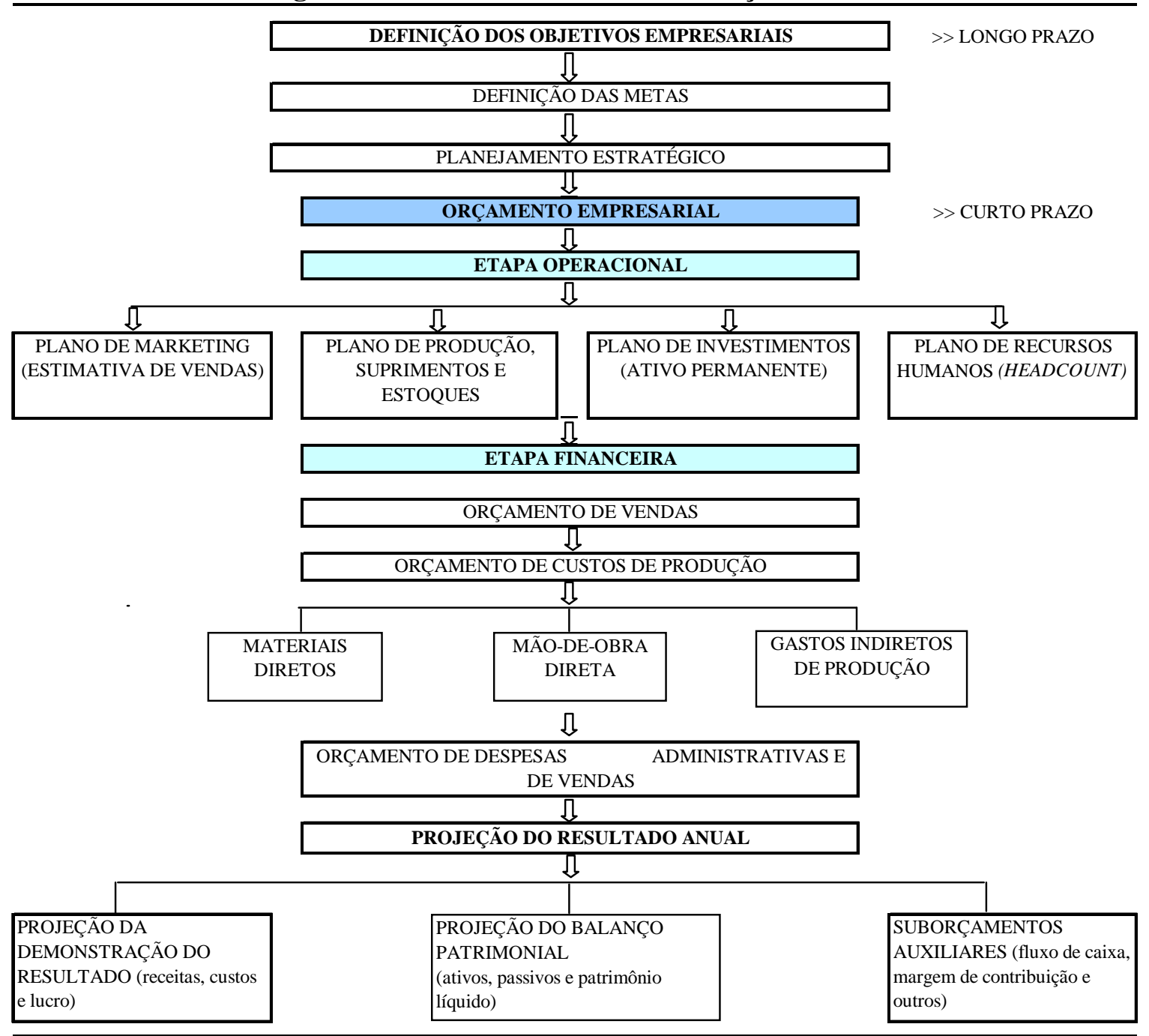

Fonte: Adaptado de WELSCH, 1983, p.93 e FREZATTI, 2006, p.46

O orçamento empresarial pode ser subdividido em duas principais etapas: operacional e financeira.

1. Etapa operacional: compreende a exploração das potencialidades da empresa. Inclui o plano de marketing, plano de produção (incluindo níveis de suprimentos e estoques desejáveis), plano de investimentos em ativo permanente e plano dos recursos humanos necessários. 
2. Etapa financeira: compreende a coleta e a consolidação das informações para composição do orçamento de vendas, custos de produção (somando materiais diretos, mão-de-obra direta e gastos indiretos de fabricação), despesas administrativas e de vendas. Com base nessas informações, chega-se à projeção anual do resultado, com a emissão de relatórios financeiros como: demonstração do resultado, balanço patrimonial, fluxo de caixa e margem de contribuição.

Após elaboração do orçamento, são realizadas análises financeiras para se verificar se o nível operacional planejado gera o resultado necessário para garantia do alcance dos objetivos propostos.

\subsubsection{Processo Orçamentário: um exemplo da indústria farmacêutica}

Na Figura 5 ilustra-se um exemplo das etapas do processo orçamentário comum em indústrias farmacêuticas de grande porte.

O objetivo desse exemplo é o de apresentar, de forma resumida, a ordem de realização e conteúdo de cada etapa do processo orçamentário, lembrando que o orçamento é parte de um plano de resultados de longo prazo.

Normalmente, nas indústrias farmacêuticas de grande porte, o processo orçamentário inicia-se em julho do ano anterior, com a elaboração do plano anual de marketing, como parte do plano estratégico de longo prazo.

Este processo, quando bem organizado, pode ser concluso num prazo de 40 a 60 dias. Isso também vai depender do tamanho da estrutura organizacional da empresa (quantidade de unidades de negócios, centros de custos e produtos) e do desempenho do sistema de 
informação utilizado para a coleta de dados, consolidação das informações e geração de relatórios.

O ideal é que o orçamento empresarial, realizado no ano anterior, seja revisado periodicamente no ano de sua execução, visando a adaptação de possíveis alterações nas projeções efetuadas.

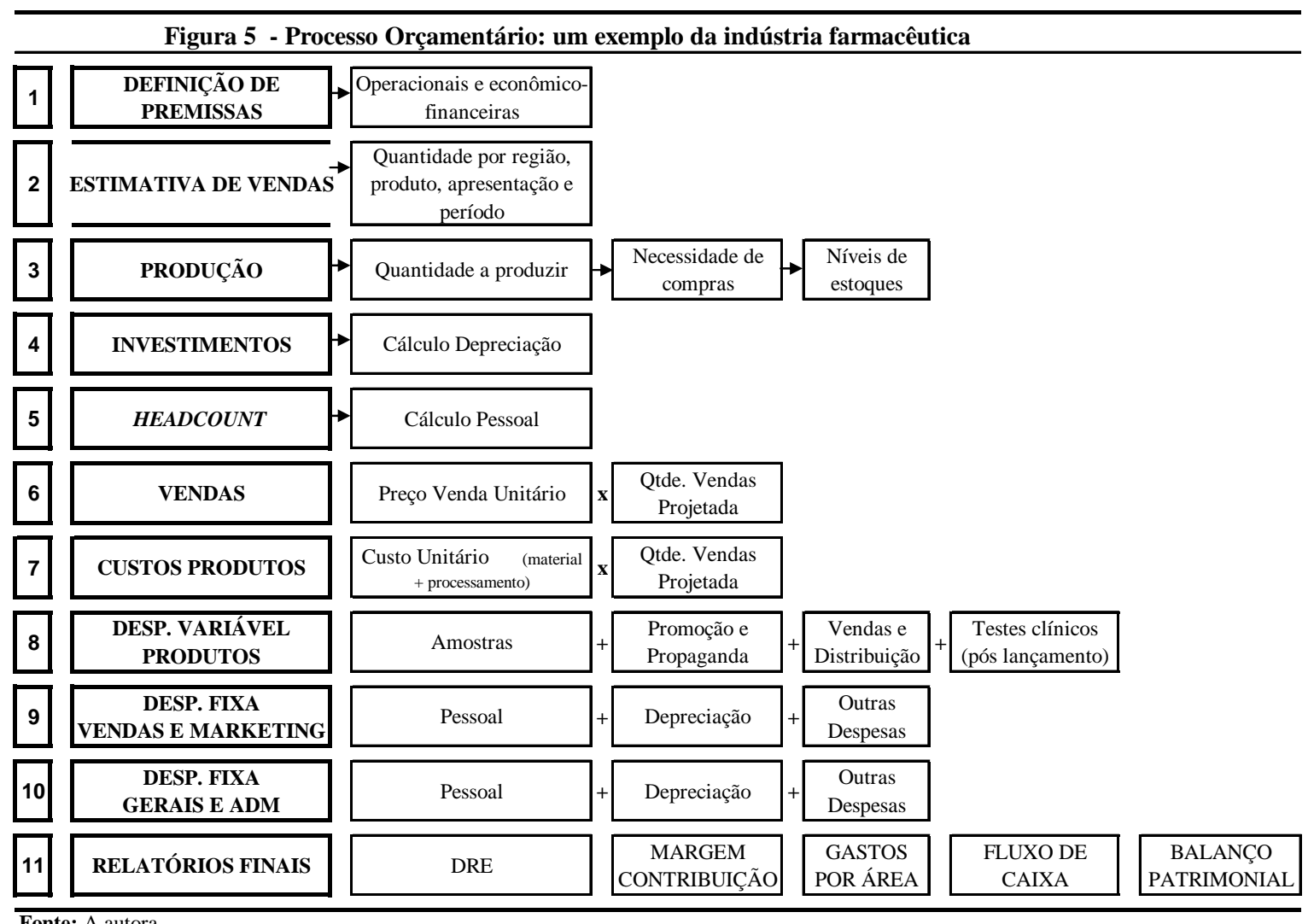

Fonte: A autora

No exemplo apresentado, o orçamento é composto por onze etapas:

1. Definição de premissas: O processo inicia-se com o estabelecimento de pressupostos básicos para a execução do orçamento propriamente dito, como capacidade produtiva e tendência de obtenção de insumos (premissas operacionais) além de taxas de inflação, câmbio, juros, variação dos preços de vendas etc. (premissas econômico-financeiras). 
2. Estimativa do volume de vendas por produto e suas apresentações: o plano anual de marketing deverá contemplar estudos mercadológicos, considerando diferentes cenários econômicos, que vão dar base para estimativa do volume das vendas a um determinado nível de preços. A estimativa do volume das vendas é um dos principais problemas do orçamento. O ideal é que esta estimativa seja feita no grau máximo de detalhamento (por forma de apresentação de cada produto) o que proporcionará melhores análises. Essa quantidade vai orientar várias outras estimativas como: investimentos, receitas, custos etc. Se as projeções não forem realizadas, conseqüentemente todos os outros orçamentos ficarão incorretos. Assim, devido a essa importância, algumas empresas adotam softwares para facilitar a previsão das vendas, alimentados continuamente pelas áreas de vendas e marketing, onde são estimadas e revistas (semanal, quinzenal ou mensalmente) as quantidades a serem vendidas nos próximos meses. Esta previsão contínua pode aumentar o nível de acurácia do orçamento de vendas e, conseqüentemente, de todo o orçamento.

3. Orçamento produção: A partir da estimativa da quantidade a ser vendida e considerando-se os níveis de estoques desejáveis, elabora-se a previsão da quantidade a ser produzida. Esta previsão também servirá como base para cálculo do consumo de materiais diretos, mão-de-obra direta e outros gastos na produção.

4. Orçamento de investimentos: nesta etapa, cada uma das áreas ou centros de responsabilidade define os valores, datas e tipos de ativos imobilizados que serão adquiridos no ano seguinte. Esse orçamento deve refletir a parte de um planejamento de investimentos de longo prazo. Os valores orçados servirão de base para cálculo dos gastos com depreciação, por área e datas, que deverão ser inclusos no orçamento das áreas. 
5. Orçamento de headcount: paralelamente ao orçamento de investimentos, poderá ser iniciada a coleta de informações sobre o número de pessoas de que vão necessitar, em cada área, no ano seguinte. O gestor de cada área deverá informar as novas contratações, eventuais demissões, transferências, aumentos de salários e concessão de benefícios etc. Essas informações servirão de base para o cálculo dos gastos com pessoal, inclusive encargos, por área e data. O cálculo pode ser feito pela equipe de recursos humanos (remuneração e benefícios) ou pela própria equipe de planejamento.

6. Orçamento de vendas: consiste na projeção da receita total para o ano seguinte, por produto e período. Multiplica-se a quantidade mensal estimada de vendas pelo preço de venda unitário previsto, por apresentação do produto, por unidade de negócio, por região e por período.

7. Orçamento dos custos dos produtos vendidos: tendo em mãos a estimativa das quantidades a serem vendidas, por produto e por mês, a área de custos, comum em grandes indústrias, informa a estimativa do custo-padrão unitário para cada produto e período. De posse dessas informações, o orçamento de custos é obtido pela multiplicação do custo unitário pela quantidade estimada de vendas de cada produto por mês. Caso seja necessária a alteração do custo-padrão, os responsáveis pela fábrica deverão elaborar o orçamento da produção, seguido pelos orçamentos de compra de matéria-prima, mão-deobra direta e custos indiretos de fabricação, que fornecerão a nova estimativa do custo unitário por produto. 
8. Orçamento das despesas variáveis por produto: devido à necessidade de obtenção dos resultados por unidade de negócio e por produto, para avaliar a contribuição e desempenho desses e de seus gestores, tanto a receita quanto os custos e despesas deverão ser orçados por produto. Nesta etapa são estimadas as despesas com distribuição de amostras, propaganda, promoções, comissões de vendas, fretes, testes clínicos etc., por produto e por data. Esse orçamento deve ser elaborado pelo gerente de marketing do produto, com base no plano anual de marketing para o período orçado; algumas informações são repassadas pela área comercial ou pela pesquisa clínica.

\section{Orçamento das despesas fixas da força de vendas e de marketing:}

a. despesas fixas da força de vendas: refere-se à estimativa dos gastos com estrutura fixa da área comercial. Inclui despesas com diretoria, treinamento, escritórios, depreciação, viagens, transportes, parte fixa da remuneração dos vendedores etc. A área responsável por esses números é a diretoria comercial. Esses gastos eventualmente poderão ser distribuídos aos produtos com base em critérios de rateios que envolvem, por exemplo, o número médio de visitas aos médicos para promoção de cada produto. Essa distribuição também permitirá melhor avaliação da contribuição do produto para o resultado da unidade de negócios a que pertence e de toda a empresa.

b. despesas gerais de marketing: compreende a estimativa dos gastos estruturais de marketing de cada unidade de negócios. Envolve despesas com salários da diretoria, gerentes de produto, analistas, viagens, pesquisas de marketing, realização de eventos para médicos, serviços de atendimento ao consumidor, 
depreciação etc. Caso a empresa adote uma área de marketing comum, os gastos poderão ser distribuídos para cada unidade de negócio. Essas informações vão compor a projeção do resultado de cada unidade de negócio.

10. Orçamento das despesas fixas, gerais e administrativas: refere-se ao orçamento de despesas com as áreas: financeira, controladoria, recursos humanos, informática, compras, jurídica, administração do prédio etc. Aí estão inclusas as despesas com salários e encargos, treinamento, depreciação, viagens, consultorias etc. Parte dos gastos poderá ser transferida para a unidade de negócio ou outra área que o solicitou. Exemplos: despesas de informática alocadas com base no número de usuários; despesa de aluguel distribuída de acordo com o tamanho de cada área. O gerente ou coordenador da área é responsável por esse orçamento.

11. Consolidação e elaboração dos relatórios: coletadas as informações, o próximo passo é a consolidação e geração de relatórios a serem utilizados para análise global do orçamento. Os relatórios mais comuns são:

a. a projeção da demonstração do resultado para o período orçado (mensal e anual), por unidade de negócio e para toda a empresa. Essa demonstração tem a mesma estrutura de uma demonstração do resultado (DRE), elaborada pela contabilidade fiscal, para a apuração do resultado do período;

b. a projeção da margem de contribuição de cada produto, grupo de produtos e unidade de negócio - mostra a receita total de cada produto, deduzindo-se todos os custos e despesas diretamente alocados a ele. Esse relatório possibilita avaliar a 
contribuição de cada produto para a cobertura dos custos e despesas fixas e para a composição do lucro da empresa;

c. a projeção de gastos por área, lista os custos ou despesas previstos por cada centro de responsabilidade e por período, permitindo controle o seu controle e avaliação do desempenho do gestor.

d. a projeção do fluxo de caixa, gerado pelas atividades planejadas por unidade de negócio e por toda a empresa, permite a apuração antecipada das sobras ou insuficiências mensais de dinheiro, por meio da confrontação das entradas de caixa, somadas ao saldo inicial e deduzidas as saídas previstas. De posse dessa projeção, o administrador do caixa poderá tomar decisões antecipadas quanto à necessidade de aplicação ou captação de recursos e definir ações visando otimizar a utilização dos recursos financeiros;

e. a projeção do balanço patrimonial informa a situação patrimonial da empresa resultante das atividades orçadas, permitindo a apuração de indicadores financeiros que poderão ser utilizados para análise e avaliação da própria proposta orçamentária.

Após a consolidação das informações e elaboração dos relatórios, a proposta final do orçamento é apresentada à diretoria geral para avaliação, aprovação e posterior divulgação aos responsáveis pela sua execução. São esses relatórios também que, após confrontação com os valores realizados, vão permitir o acompanhamento e controle orçamentário e, conseqüentemente, a tomada de decisões pelos gestores. 


\subsubsection{Avaliação, Aprovação e Divulgação do Orçamento}

Conclusas as projeções, a área responsável pelo orçamento realiza análises para verificar se os valores apresentados para o próximo ano coincidem com os objetivos empresariais e, conseqüentemente, com as expectativas dos acionistas ou sócios.

Para a avaliação da proposta orçamentária, FREZATTI (2006, p. 77) sugere a utilização de alguns instrumentos de análise financeira; entre eles:

- a taxa de retorno sobre o patrimônio líquido;

- a taxa de retorno sobre os investimentos totais;

- a relação custo-volume-lucro;

- os níveis de geração de caixa;

- participação percentual das despesas sobre o faturamento;

- outros índices operacionais e financeiros (índices de liquidez, de rentabilidade, de atividade);

- EVA (economic value added) e o EBITDA (earnings before interest, tax, depreciation and amortization).

O resultado dessas análises será apresentado à alta direção da empresa para aprovação, podendo ser solicitados ajustes, caso os valores não estejam concordes com os objetivos da organização.

A projeção desses indicadores vai facilitar o monitoramento, acompanhamento e controle dos resultados durante a execução do plano. (KRUEGER, in Corporate Controller's Manual, 1998, p. D4-15 
Finalmente, cumprindo o princípio da comunicação integral abordado no item 2.3.1 deste capítulo, após a aprovação o orçamento deve ser divulgado para todos os responsáveis pelas áreas envolvidas na sua confecção. TUNG (1994, p. 397) sugere que cada área receba apenas a parte do orçamento referente às suas responsabilidades.

Iniciada a execução do orçamento, é necessário o controle gerencial.

\subsubsection{Vantagens e Limitações do Orçamento}

De forma resumida, antes de serem executadas ações para se atingirem objetivos, as empresas devem planejar, ou seja, simular a sua implementação, visando à minimização dos seus riscos e falhas.

Quanto à necessidade de formalização do processo orçamentário, essa vai depender do ramo de atividade e porte da empresa. No caso das empresas de estrutura reduzida, o grau de formalização poderá ser menor, diminuindo os custos e aumentando a eficácia do processo.

As potencialidades do orçamento empresarial foram listadas no decorrer desta revisão teórica, no entanto cabe aqui reforçar as vantagens e limitações da adoção de um processo estruturado de planejamento e controle.

\subsubsection{Vantagens}

Grande parte dos autores citados nesta revisão lista vantagens similares proporcionadas pela formalização de um processo orçamentário.

São vários os benefícios enumerados. Aqui serão citados alguns dos principais estabelecidos por WELSCH (1983, p.64) e confirmados por FREZATTI (2006, p. 10): 
a. facilita a coordenação de atividades de maneira apropriada;

b. permite tomar decisões antecipadamente sobre os cursos de ações;

c. proporciona comprometimento dos gestores antes da decisão e implementação do plano;

d. promove mais transparência entre as áreas da empresa;

e. exige a definição das funções e responsabilidades de cada área de resultado da empresa;

f. obriga o gestor a utilizar os recursos disponíveis de forma mais eficiente;

g. proporciona maior e melhor entendimento entre as áreas envolvidas, pois todas buscam atingir os objetivos da empresa toda;

h. força cada área e seus gestores a analisarem se os seus objetivos e desafios estão de acordo com suas aspirações;

i. permite a avaliação do progresso da realização dos objetivos e do desempenho das áreas e seus gestores.

Para conseguir esses benefícios, o orçamento pressupõe a observação dos princípios gerais de planejamento, citados no item 2.31.

\subsubsection{Limitações}

Apesar de todas as vantagens citadas, os autores reconhecem a existência de algumas barreiras à implantação de um sistema orçamentário.

Frezatti, corroborado por Welsch, citados no item 2.3.5.1, sugerem a análise dos seguintes possíveis obstáculos: 
a. os dados orçados são somente estimativas. Estão, assim, sujeitos a erros;

b. o custo do sistema, caso não seja adaptado ao porte da empresa;

c. necessidade de revisões periódicas para adequar o orçamento às circunstâncias;

d. elaboração e execução realizadas por pessoas tecnicamente capacitadas e motivadas;

e. o plano não substitui a administração; não deve ser seguido à risca sem a avaliação e observação, por parte dos gestores, das reais necessidades da empresa.

Essas limitações foram aqui lembradas não como razões impeditivas da elaboração do orçamento, mas como pontos a serem observados e discutidos antes do início do processo.

\subsection{CONTROLE GERENCIAL}

O orçamento empresarial vai permitir ao gestor controlar se as decisões tomadas foram executadas e levaram ao cumprimento dos objetivos da empresa.

O Controle Gerencial é conceituado por ANTHONY e GOVINDARAJAN (2001, p. 34) como o processo pelo qual os executivos de uma empresa influenciam outros funcionários da organização, para que obedeçam às estratégias adotadas.

Assim, para esses autores, o Controle Gerencial é um instrumento de implementação de estratégias, pois auxilia a administração a conduzir a organização na direção de seus objetivos estratégicos.

O gestor confronta as metas com os resultados alcançados. As variações numéricas entre eles devem ser analisadas para se entenderem as causas da variação e se tomarem ações que ajustem as metas no futuro ou que permitam manter aquelas que foram decididas. É o 
controle orçamentário que vai realimentar ou revisar o planejamento estabelecido. (FREZATTI, 2006, p. 80)

Utilizando mecanismos de controle, o gestor deve apurar e analisar as variações entre o orçamento e o que foi efetivamente realizado, tomar conhecimento das causas que levaram a tais variações, implementar ações corretivas e realimentar o processo de planejamento, objetivando a maximização da riqueza dos proprietários da empresa.

Para que o orçamento seja utilizado como forma de controle gerencial, devem ser elaborados relatórios específicos por áreas de responsabilidade (centros de lucro, centros de custo e centros de investimentos). Esses relatórios vão mostrar as variações entre o planejado e o realizado, servindo também para o gestor avaliar o colaborador responsável. (CORR e HILL, in Wendell’s Manual, 1998)

A análise das variações é um instrumento poderoso de administração, mas há limitações. A mais importante delas está em identificar somente o local em que ocorreu a variação, mas não indicando a razão de sua ocorrência nem que providências devem ser tomadas. (ANTHONY e GOVINDARAJAN, 2001, p. 528)

Mesmo com algumas limitações, os controles gerenciais podem constituir uma ferramenta essencial para que os executivos pensem em novas estratégias, isto é, decidam sobre o destino da organização. Pesquisas recentes nos Estados Unidos apontam que 95\% das empresas tidas como bem administradas utilizam o controle orçamentário. (PASSARELLI e BOMFIM, 2004, p.18)

Partindo das informações contidas nas teorias apresentadas e da sua experiência profissional, na área de planejamento e controle de uma indústria farmacêutica de grande porte, a autora pretende investigar a utilização do orçamento empresarial nas indústrias farmacêuticas de médio porte. Pretende também verificar se o orçamento empresarial é 
considerado, por parte dos gestores empresariais, uma ferramenta de apoio a eles na tomada de decisões e no controle gerencial. 


\section{METODOLOGIA}

\subsection{CARACTERIZAÇÃO DA PESQUISA}

Pesquisa é um “procedimento reflexivo sistemático, controlado e crítico, que permite descobrir novos fatos ou dados, relações ou leis, em qualquer campo do conhecimento”, ou seja, é um procedimento formal com método de pensamento reflexivo, que exige um tratamento científico e constitui-se no caminho para conhecer a realidade ou para descobrir verdades parciais. (ANDER-EGG, apud LAKATOS; MARCONI, 2006, p. 157)

A escolha do método de pesquisa é um dos pontos principais, visto que são as informações obtidas por meio dele que vão possibilitar a análise e a conclusão do que está sendo proposto.

Para que os objetivos deste trabalho pudessem ser alcançados, optou-se por uma pesquisa qualitativa exploratória aplicada a estudo de casos múltiplos, em indústrias farmacêuticas consideradas de médio porte.

A pesquisa qualitativa ocupa-se da investigação de eventos qualitativos, aqueles representados por dados qualitativos, com referenciais teóricos menos restritivos e com maior oportunidade de manifestação para a subjetividade do pesquisador. (PEREIRA, 1999, p.21)

“Os estudos de caso são a estratégia preferida quando o pesquisador tem pouco controle sobre os acontecimentos e quando o foco se encontra em fenômenos contemporâneos em algum contexto da vida real” (YIN, 2005, p. 20-25). Para esse autor, o estudo de caso vem sendo comumente utilizado em pesquisas relacionadas ao campo da Administração.

Os estudos exploratórios são investigações por meio de pesquisa empírica com o objetivo de formular questões para o desenvolvimento de hipóteses, aumento da familiaridade 
com o ambiente e o tema, visando esclarecer os conceitos para a elaboração de pesquisas futuras mais precisas. (MARCONI e LAKATOS, 2006, p. 190)

Assim, quanto ao propósito desta pesquisa, é necessário que seja exploratório já que o conhecimento disponível sobre o uso do orçamento empresarial em indústrias farmacêuticas de médio porte é insuficiente para se estabelecerem as relações de causa e efeito.

\subsection{MODELO CONCEITUAL}

O modelo conceitual, desenvolvido para esta pesquisa, verificará se o orçamento empresarial é considerado uma ferramenta de apoio às decisões e ao controle gerencial. Será analisado o modelo do processo orçamentário adotado por cada empresa, observando-se se ele é adequado, com base nos princípios gerais de planejamento sugeridos por Welsch (1983, p. 48) e corroborados por Frezatti (2006, p. 45). Este modelo está ilustrado na Figura 6.

Figura 6 - Variáveis da Pesquisa

\begin{tabular}{|c|c|c|}
\hline $\begin{array}{c}\text { Variável } \\
\text { Independente }\end{array}$ & $\begin{array}{c}\text { Variável } \\
\text { Interveniente }\end{array}$ & $\begin{array}{c}\text { Variável } \\
\text { Dependente }\end{array}$ \\
\hline
\end{tabular}




\subsubsection{Variáveis da Pesquisa}

“Uma variável pode ser considerada como uma classificação ou medida; uma quantidade que varia; um conceito operacional, que contém ou apresenta valores; aspecto, propriedade ou fator, discernível em um objeto de estudo e passível de mensuração” (MARCONI; LAKATOS, 2006, p. 139)

De acordo com esses autores, adicionam-se ao conceito operacional, que pode ser um objeto, um processo, um fenômeno, um problema etc., valores para transformá-lo em variável. Esses valores são quantidades, qualidades, características, magnitudes, traços etc., diferentes em cada caso particular.

Do segundo para o terceiro “universo” da ciência, quando ocorre o enunciado das variáveis, ou seja, quando se passa do estágio da observação (de fatos, fenômenos, comportamentos, atividades reais) às hipóteses.

Em estudos de caso, não há necessidade de formulação de hipóteses. Mesmo assim, julga-se importante definir as variáveis na validação das teorias que apóiam a pesquisa.

A seguir, os conceitos dos tipos de variáveis apresentados no desenho desta pesquisa (Figura 6), segundo Marconi e Lakatos (2006, p. 140-152):

\subsubsection{Variável Independente}

“É a variável que influencia, determina ou afeta outra variável; é fator determinante, condição ou causa para determinado resultado, efeito ou conseqüência”. Ela é manipulada e controlada para que seus efeitos sobre a variável dependente sejam medidos. 
A variável independente deste estudo é o uso do orçamento empresarial como ferramenta de apoio à tomada de decisões e ao controle gerencial. Ela será medida pela opinião direta dos gestores.

- Possuir sistema de informação contábil-gerencial: indica que a empresa se preocupa em gerar informações contábil-gerenciais (orçamento, contabilidade e custos), para serem utilizadas para a tomada de decisão e para o controle gerencial.

- Aplicar princípios gerais de planejamento: indica o grau de adequação processo orçamentário adotado.

\subsubsection{Variável Interveniente}

“É aquela que, numa seqüência causal, se coloca entre a variável independente (X) e a dependente (Y), tendo como função ampliar, diminuir ou anular a influência de X sobre Y”. Ela é conseqüência da variável independente e determinante da variável dependente.

Como variável interveniente, elegeu-se o processo orçamentário adequado, medido pela concordância dos entrevistados com a aplicação dos princípios gerais de planejamento pela empresa.

\subsubsection{Variável Dependente}

“Consiste naqueles valores (fenômenos, fatores) a serem explicados ou descobertos, em virtude de serem influenciados, determinados ou afetados pela variável independente; é o fator que aparece, desaparece ou varia à medida que o investigador introduz, tira ou modifica a variável independente”. 
Neste estudo, a variável dependente são as informações geradas pelo orçamento empresarial, disponíveis para tomada de decisão e para controle gerencial. Esta variável será medida pela opinião dos gestores.

\subsection{PROCEDIMENTO DE CAMPO}

As informações necessárias para a pesquisa foram coletadas sob condições de ambiente não controlado, ou seja, no contexto de vida real, por meio de entrevistas pessoais desenvolvidas pela pesquisadora.

O primeiro passo foi a definição da amostra, ou seja, as indústrias farmacêuticas de médio porte que seriam estudadas.

Segundo COLLIS e HUSSEY (2005, p. 148), uma amostra é formada por alguns membros ou grupos de uma população, e esta é qualquer compilação de itens considerados.

MATTAR (1997, p. 266) estabelece e conceitua dois tipos de amostra: a probabilística e a não-probabilística:

- probabilística: “Aquela em que cada elemento da população tem uma chance conhecida e diferente de zero de ser selecionado para compor a amostra”. É baseada no conceito de seleção aleatória.

- não probabilística: “Aquela em que a seleção dos elementos da população para compor a amostra depende, ao menos em parte, do julgamento do pesquisador ou do entrevistador no campo”.

Este autor complementa que o processo de amostragem depende do tipo de pesquisa, da disponibilidade e acessibilidade aos elementos da população, da representatividade 
desejada ou necessária e dos recursos, sejam eles materiais, financeiros e humanos disponíveis.

Com relação à extensão da amostra, as indústrias farmacêuticas a serem pesquisadas foram escolhidas intencionalmente (ou por julgamento), atendendo ao critério de proximidade geográfica e interesse dos respondentes em participar. (COOPER e SCHINDLER, 2003, p. 169)

O objetivo da pesquisa é o de estudar indústrias farmacêuticas consideradas de médio porte, adotado o critério número de empregados, conforme Tabela 1, apresentada no Capítulo 1, item 1.1.

Assim, com base na listagem de indústrias farmacêuticas constante do relatório “Ranking de Laboratórios”, levantado por intermédio do GRUPEMEF em julho de 2007, a pesquisadora entrou em contato com várias empresas situadas na cidade de São Paulo, questionando sobre o número de empregados e o interesse em participar do estudo.

Dessa forma, participam deste estudo de caso múltiplo cinco indústrias farmacêuticas consideradas de médio porte, ou seja, aquelas que contam com 100 a 499 empregados, situadas na cidade de São Paulo.

Essas empresas solicitaram que seus nomes não fossem divulgados, portanto consideram-se, neste trabalho, empresas A, B, C, D e E.

\subsubsection{Amostra}

\subsubsection{Empresa A}

Indústria farmacêutica atuante no mercado brasileiro há quase 60 anos, pertencente a grupo estrangeiro. O principal administrador da empresa no Brasil gerencia cerca de 300 funcionários, entre colaboradores efetivos e terceirizados. 
O seu faturamento em 2007 foi de aproximadamente R\$100 milhões e suas vendas são voltadas totalmente para o mercado interno.

O contato para a entrevista foi o gerente administrativo-financeiro da sucursal brasileira, um profissional maduro e com vasta experiência em grandes organizações ligadas ao mercado farmacêutico.

\subsubsection{Empresa B}

Empresa com capital de origem estrangeira, presente em 70 países.

A unidade brasileira conta com cerca de 180 empregados. Faturou aproximadamente R\$110 milhões em 2007, com vendas exclusivas no mercado interno.

A entrevista foi realizada diretamente com o seu diretor financeiro, jovem, recentemente contratado e com experiência tanto no ramo farmacêutico quanto em outros setores.

\subsubsection{Empresa C}

Indústria farmacêutica atuante no Brasil há cerca de 30 anos, possui aproximadamente 100 empregados, entre contratados e terceirizados.

Seu capital é de origem estrangeira. As vendas da unidade brasileira são totalmente voltadas para o mercado interno.

O gerente financeiro, um experiente profissional, foi o nosso entrevistado.

\subsubsection{Empresa D}

Empresa de capital estrangeiro no Brasil há 12 anos, conta com cerca de 160 empregados. 
Além da divisão farmacêutica, a empresa comercializa materiais médico-hospitalares. Faturou, em 2007, aproximadamente $\mathrm{R} \$ 150$ milhões, dos quais $\mathrm{R} \$ 100$ milhões foram referentes à divisão de produtos farmacêuticos. Suas vendas são $100 \%$ voltadas para o mercado interno.

O seu diretor financeiro, profissional experiente no ramo farmacêutico, e um analista financeiro foram os contatos durante a entrevista.

\subsubsection{Empresa $\mathbf{E}$}

Empresa de capital estrangeiro com cerca de 300 empregados está no Brasil há aproximadamente 20 anos.

Em 2007, seu faturamento chegou à casa dos R \$100 milhões. Seu alvo é somente o mercado interno.

A diretoria financeira está a cargo de um jovem profissional, que foi o contato na entrevista.

As empresas escolhidas permitiram a inferência sobre a elaboração do orçamento empresarial, as informações geradas por ele e seu uso como ferramenta de apoio à tomada de decisões e ao controle gerencial.

\subsubsection{Coleta de Dados}

Segundo Lakatos e Marconi (2006, p. 167), a coleta de dados é a “etapa da pesquisa em que se inicia a aplicação dos instrumentos elaborados e das técnicas selecionadas, a fim de se efetuar a coleta dos dados previstos”. 
Em estudos de caso, a coleta de evidências pode ser feita por meio de seis diferentes fontes: documentos, registros em arquivo, entrevistas, observação direta, observação participante e artefatos físicos. (YIN, 2005, p. 109).

Esse autor complementa que alguns princípios devem ser observados, por ocasião da coleta de dados, visando a um estudo de qualidade:

a. utilizar várias fontes de evidências;

b. montar um banco de dados com informações para o estudo de caso;

c. haver um encadeamento de evidências, ou seja, ligações explícitas entre as questões feitas, os dados coletados e as conclusões a que se chegou.

Em virtude da característica desta pesquisa, principalmente pelo fato de não ser permitida a divulgação dos nomes das empresas, dos dados confidenciais de uso interno, bem como de informações adicionais, optou-se pela coleta de evidências somente por intermédio de entrevistas.

A entrevista é uma das mais importantes fontes de informações para um estudo de casos, além disso são fontes essenciais de informações para este tipo de estudo. (YIN, 2005, p. 116).

O tipo de entrevista adotado foi o estruturado (ou padronizado), ou seja, aquela em que o entrevistador segue um roteiro previamente estabelecido. Neste caso, as perguntas propostas ao entrevistado são predefinidas em formulário e existe um roteiro prévio para a entrevista. (LAKATOS; MARCONI, 2006, p. 199). O formulário utilizado consta do Anexo I deste estudo.

Yin (2005, p. 113) lista pontos fortes e pontos fracos dessa fonte de evidência. Na opinião desse autor, o principal ponto forte de uma entrevista direcionada está em ela enfocar 
diretamente o tópico do estudo de caso, economizando tempo dos entrevistados e também do entrevistador. A entrevista, porém, pode apresentar alguns pontos fracos como: possíveis vieses devido a questões mal-elaboradas; respostas enviesadas devido à memória fraca do entrevistado; e "reflexibilidade”, ou seja, o entrevistado responde ao entrevistador o que este quer ouvir.

As entrevistas foram realizadas nas próprias empresas utilizando-se roteiro predefinido com as questões abordadas. Ver Anexo II.

O roteiro da entrevista compõe-se de quatro blocos de questões, que evidenciam a aplicabilidade do orçamento empresarial como ferramenta de apoio às decisões e ao controle gerencial:

1. informações gerais sobre a empresa;

2. informações sobre o sistema de informação contábil-gerencial e o uso do orçamento empresarial;

3. informações sobre as etapas do processo orçamentário adotado;

4. aplicação dos princípios gerais de planejamento.

Nos três primeiros blocos, as questões são uma combinação de respostas de múltipla escolha com as respostas abertas, o que possibilita mais informações sobre o assunto (MARKONI; LAKATOS, 2006, p. 209)

O primeiro bloco abordou a estrutura da empresa: principal executivo da empresa, estrutura legal da empresa, origem do capital, número de empresas, tempo de atividade no Brasil, faturamento bruto anual da divisão farmacêutica, número de empregados e o destino das vendas. 
O sistema de informações gerenciais e o uso do orçamento empresarial foram o tema do segundo bloco de questões. O objetivo é o de saber quais são e como são geradas as informações necessárias para a tomada de decisões e para controle gerencial, conforme abordado na revisão teórica. Foi questionado o uso do orçamento empresarial, da contabilidade geral e de custos (2.1). Indagou-se também sobre o sistema de informática utilizado para armazenamento dos dados e os tipos de relatórios gerados e utilizados pelos gestores.

Questões sobre as etapas do processo orçamentário adotado pela empresa foram feitas no terceiro bloco, buscando verificar-se a teoria apresentada no Capítulo 2 (item 2.3) e também a realização do planejamento estratégico (item 2.2) e do controle gerencial (item 2.4).

Finalmente, no quarto e último bloco, foi questionada a opinião do entrevistado sobre a aplicação dos princípios gerais de planejamento pela empresa. Para tanto foi oferecida uma escala quantitativa, com notas de zero a dez. O entrevistado deveria assinalar o número que reflete o grau de concordância do entrevistado com a aplicabilidade de cada um dos princípios apresentados na revisão teórica (item 2.3.1): envolvimento administrativo, adaptação organizacional, contabilidade por área de responsabilidade, orientação para objetivos, comunicação integral, expectativas realistas, oportunidade, aplicação flexível, reconhecimento do esforço individual e do grupo e acompanhamento.

Na Tabela 2 apresentam-se as notas para a avaliação do processo orçamentário, elaborada pela autora.

\begin{tabular}{cc}
\hline Tabela 2 - Escala para Avaliação do Processo Orçamentário \\
\hline Notas & Avaliação do processo \\
\hline $0-2,5$ & inadequado \\
\hline $2,5-5$ & pouco adequado \\
\hline $5-7,5$ & relativamente adequado \\
\hline $7,5-10$ & adequado \\
\hline Fonte: Proposta da autora &
\end{tabular}




\subsection{TRATAMENTO DOS DADOS}

Objetivando a identificação dos aspectos discutidos na revisão teórica, o tratamento dos dados foi realizado com análises qualitativas dos conteúdos obtidos nas entrevistas. A estratégia geral de análise dos dados baseou-se nas proposições teóricas discutidas no Capítulo 2, fundamentadas nos conceitos e aplicações do sistema de informações gerenciais, do planejamento estratégico, do orçamento empresarial e do controle gerencial.

A técnica analítica específica utilizada para a análise do estudo de casos desta pesquisa foi a de adequação ao padrão, sugerida por YIN (2006, p. 137) para estudo de casos múltiplos. Esta técnica é composta de uma explanação sobre as empresas entrevistadas, cujo propósito é a identificação de ligações causais, que justifiquem a preparação e a utilização do orçamento empresarial como ferramenta de apoio à tomada de decisões e ao controle gerencial.

\subsection{LIMITAÇÕES DO MÉTODO}

A escolha do estudo de casos múltiplos como estratégia de pesquisa traz limitações e exige cuidados.

Foram considerados, nesta pesquisa, os seguintes pontos de atenção:

- visão limitada aos cinco casos estudados, não podendo ser generalizada;

- possível viés por parte dos entrevistados, buscando valorizar o seu trabalho. Neste caso, um ponto positivo é o conhecimento e a prática da entrevistadorapesquisadora em orçamento empresarial, garantindo maior confiabilidade no conteúdo da entrevista, mas não eliminando em sua totalidade os desvios de percepção. 


\section{ESTUDO DE CASOS}

Num primeiro momento, será relatado cada caso e, ao final, uma visão geral das cinco empresas.

\subsection{EMPRESA A}

\subsubsection{O sistema de informação contábil-gerencial}

Na empresa A, o setor chamado Contabilidade é o responsável pela geração das informações contábil-gerenciais. Mesmo com este nome, realiza todas as atividades de responsabilidade da Controladoria: planejamento, controle, contabilidade geral e de custos. Segundo o entrevistado, “não há necessidade da área de Controladoria”, já que o setor realiza todo o trabalho necessário.

Esta área cuida da coleta e registro dos dados contábeis, da elaboração dos relatórios exigidos pelos órgãos fiscais e também da apuração dos custos dos produtos. Para tanto utiliza o sistema de informática sueco IFS (Industrial Financial Systems), que consolida, armazena e gera informações contábeis referentes a duas unidades de negócios, subdivididas em trinta centros de responsabilidade, distribuídos entre as áreas industrial, comercial e administrativa.

O orçamento empresarial é elaborado por esse setor e o sistema de informática utilizado é o Microsoft Excel.

Questionado sobre a eficiência desses sistemas, o entrevistado respondeu que não vem atendendo satisfatoriamente às necessidades.

Os relatórios contábil-gerenciais são preparados e disponibilizados mensalmente, até cinco dias após o fechamento contábil, aos gestores. São eles: demonstração do resultado, margem de contribuição por unidade de negócio e demonstrativo de gastos por área de 
responsabilidade. Todos eles contêm um comparativo entre os números realizados e orçados, permitindo a análise de variações.

$\mathrm{Na}$ opinião do entrevistado, o gerente administrativo-financeiro, o orçamento empresarial pode ser considerado uma ferramenta de apoio às decisões e ao controle gerencial. Na sua percepção, os demais gerentes concordam com essa opinião.

\subsubsection{O planejamento}

Quando questionado sobre a existência de processo formal de planejamento, o entrevistado respondeu que possui e é eficiente. No entanto, verificou-se que não é elaborado o plano de resultado nem definidas estratégias para longo prazo. A resposta apresentada foi que "é no curto prazo que as coisas acontecem”.

O planejamento de negócios e o estabelecimento de estratégia para cumprimento dos objetivos só é elaborado em curto prazo. O plano é realizado pela área comercial, sem a participação do gerente administrativo-financeiro, que não toma conhecimento da estratégia adotada.

\subsubsection{O orçamento empresarial}

O processo orçamentário é realizado no ano anterior e revisto três vezes durante o ano em que é executado.

A definição de premissas financeiras e operacionais é o ponto de partida, seguido do orçamento de investimentos em ativo permanente, detalhado por centro de responsabilidade. Contudo somente o orçamento de investimentos em equipamentos fabris faz parte do planejamento de longo prazo.

Existem poucas alterações no número de pessoal, por isso a etapa que visa coletar informações sobre o headcount de cada centro de responsabilidade não é executada 
antecipadamente. A área de Recursos Humanos gera as informações sobre os gastos com pessoal, considerando as premissas de correção dos salários. Os gastos previstos são enviados aos gestores de cada centro de responsabilidade simultaneamente à planilha para orçamento dos demais gastos.

A estimativa do volume de vendas é contínua e é elaborada por região e por apresentação de produto, ou seja, para cada forma de suas formas de apresentação. O trabalho é realizado com auxílio da planilha eletrônica Excel. A acurácia mensal nas estimativas de vendas é base para avaliação do desempenho dos vendedores e de suas regiões.

Com relação à produção, 95\% dos medicamentos são fabricados internamente e 5\% são comprados de terceiros. O custo-padrão atual reajustado é a base para o orçamento do custo unitário.

As despesas alocadas diretamente aos produtos são orçadas por marca de medicamento (brand) e incluem despesas de vendas (comissões e brindes) e despesas de distribuição.

Já as despesas fixas das áreas de vendas, marketing, despesas gerais e administrativas são orçadas por centro de responsabilidade. As despesas com serviços de segurança e limpeza são transferidas para as outras áreas, com base em critérios de rateio predeterminados.

A empresa produz medicamentos similares e, por isso, não possui gastos com pesquisa e desenvolvimento, pois as fórmulas são fornecidas pela matriz.

Segundo o entrevistado, não há necessidade de elaboração do orçamento anual de caixa porque “a empresa não tem endividamento”. Apesar disso, é mantida uma projeção contínua de caixa de suas sobras ou insuficiências semanalmente. De acordo com norma interna, visando melhor controle do caixa, as notas fiscais devem ser entregues no Contas a Pagar, com antecedência mínima de cinco dias úteis. 
Todos os dados são coletados e consolidados com auxílio do Excel. São gerados os seguintes relatórios: demonstração do resultado e margem de contribuição por unidade de negócios, além do demonstrativo de gastos por área de responsabilidade.

\subsubsection{O controle orçamentário}

É realizada uma reunião mensal entre o presidente e gerências para acompanhamento dos resultados realizados em comparação com o orçamento, quando são definidas ações corretivas visando ao cumprimento dos objetivos empresariais.

\subsubsection{Avaliação do processo orçamentário}

No Gráfico 3 apresenta-se a avaliação do entrevistado sobre o grau de observância dos princípios gerais de planejamento pela empresa.

A nota média recebida pela empresa é 8,2, com a nota mínima 6,0, a máxima 8,2 e desvio-padrão 1,3, indicando que, de acordo com a Tabela 2, o entrevistado acredita que a empresa tem um processo orçamentário adequado. No entanto, as notas mais baixas em alguns itens sinalizam que o processo pode ser melhorado no que diz respeito ao envolvimento administrativo no processo (nota 7,5), à comunicação interna (nota 6,5) e aos meios de reconhecimento do esforço individual e do grupo (nota 6,0).

Apesar dessa média favorável, cabem outras observações:

- o nome dado ao setor responsável pelo sistema de informações contábil-gerenciais está inadequado e deveria ser alterado para Controladoria;

- os sistemas de informática utilizados necessitam ser ajustados;

- a empresa não elabora planejamento estratégico de longo prazo o que poderá comprometer a preparação do orçamento empresarial e, conseqüentemente, o alcance dos seus objetivos gerais; 
- o orçamento de caixa não é preparado, privando os gestores de analisar antecipadamente eventuais sobras e insuficiências de caixa;

- o fato de não coletar as informações sobre headcount, numa etapa anterior à geração da planilha para captação das demais informações dos centros de responsabilidade, poderá gerar retrabalho, caso haja alterações no pessoal;

- observa-se que não é feita a projeção do balanço patrimonial, impossibilitando o cálculo da projeção do retorno sobre o investimento e sobre o patrimônio líquido (lucro líquido dividido pelo ativo total ou patrimônio líquido, respectivamente) e o ajuste desses indicadores com os objetivos gerais da empresa.

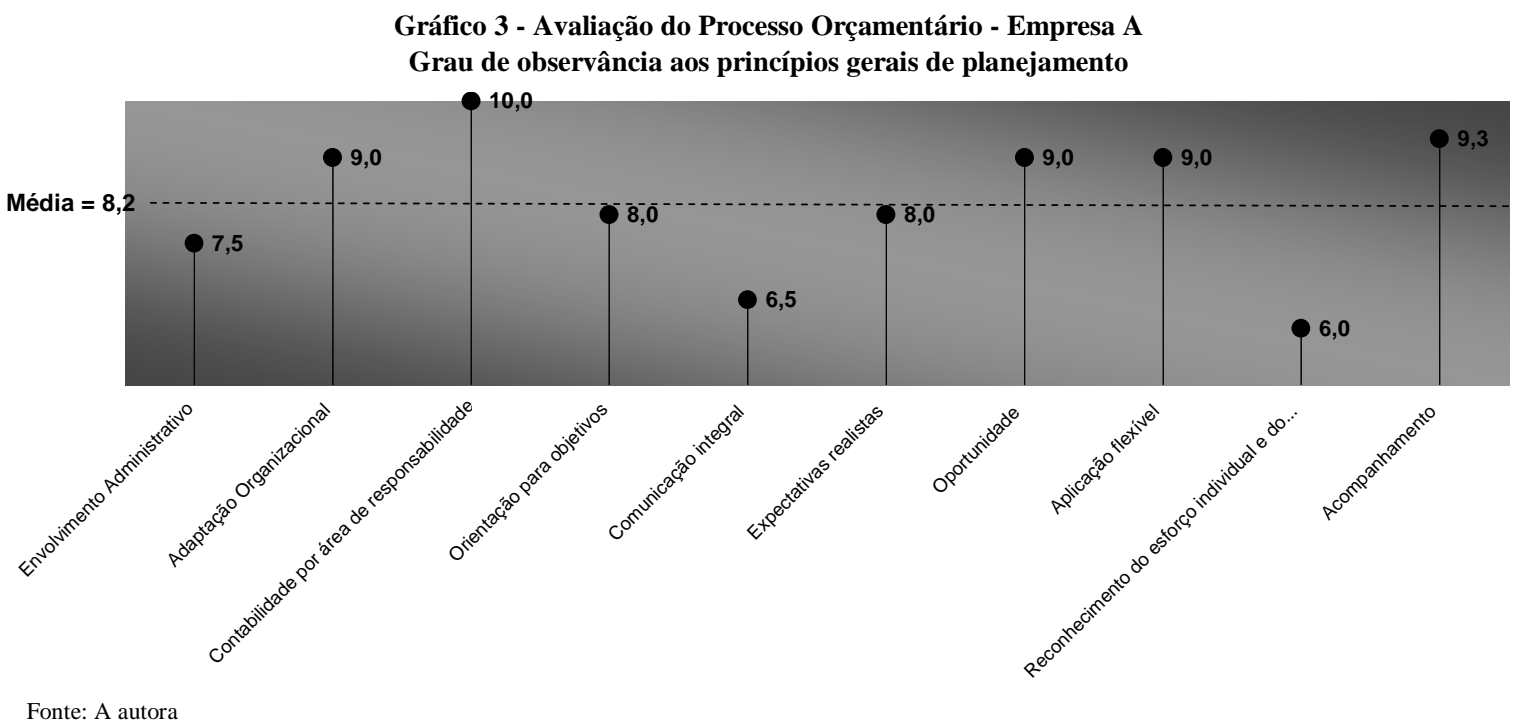

\subsection{EMPRESA B}

\subsubsection{O sistema de informação contábil-gerencial}

A Controladoria é a área responsável pelo fornecimento de informações contábilgerenciais e cuida do orçamento empresarial, controle orçamentário, contabilidade geral e de custos. 
A empresa conta com o sistema integrado de gestão alemão SAP-ERP (Enterprise Resource Planning Solutions), aplicativo R/3, que é capaz de registrar, armazenar, processar e organizar informações geradas por todos os processos da empresa. Possui também o aplicativo BW (Business Warehouse) que alimenta, com informações on-line coletadas pelo SAP, relatórios previamente estruturados. Esse sistema é utilizado para efetuar a contabilidade geral e a de custos.

Para a elaboração do orçamento empresarial, conta com o sistema americano Cognos Enterprise Planning Series.

Apesar de possuírem boas referências quanto à sua eficiência, os sistemas de informática utilizados não vêm proporcionando a agilidade esperada.

As informações contábil-gerenciais são geradas mensalmente para cada um dos gestores das suas quatro unidades de negócios, das áreas administrativas e industriais. São emitidos o demonstrativo do resultado por unidade de negócio e total da empresa, a margem de contribuição por unidade de negócio, o demonstrativo de gastos por área de responsabilidade e o fluxo de caixa.

Os relatórios contêm informações realizadas comparadas com as orçadas, permitindo análise das variações.

Segundo o diretor financeiro, que foi o entrevistado nesta empresa, todos os relatórios gerados pela Controladoria, com informações do orçamento empresarial, são efetivamente utilizados pelos gestores como apoio à tomada de decisões e controle gerencial e os gestores concordam com essa opinião.

\subsubsection{O planejamento}

A empresa B possui um processo formal de planejamento das atividades, mas, na opinião do entrevistado, necessita de ajustes. 
É elaborado o plano de resultado de longo prazo, quando são definidas estratégias de ação para cumprimento dos objetivos de longo prazo. Com base nessas definições, é preparado um plano de negócios anual, que servirá de base para a elaboração do orçamento empresarial.

\subsubsection{O orçamento empresarial}

O processo orçamentário tem início no ano anterior com a definição de premissas operacionais e financeiras.

O passo seguinte consiste no orçamento das necessidades de investimento, que é parte de um plano de longo prazo por centro de responsabilidade.

Paralelamente ao orçamento de investimento, são coletadas informações sobre alterações no quadro de pessoal. Nesta etapa, cada centro de responsabilidade informa eventuais admissões, demissões, promoções, aumentos de salário, inclusão ou exclusão de benefícios, transferências, etc. Estas informações são repassadas para a área de Recursos Humanos responsável pelo cálculo do orçamento de pessoal para cada área.

Com relação ao orçamento de vendas, primeiramente é validada, pela gerência de marketing, a estimativa do volume de unidades a serem vendidas por produto. A base de dados é a projeção contínua realizada pela força de vendas, considerando-se também as estratégias promocionais para o ano seguinte.

Essas informações são repassadas para a Controladoria para cálculo do orçamento de vendas e também encaminhadas para a fábrica, para a preparação do orçamento de produção.

A projeção do custo unitário é baseada no custo-padrão determinado pela matriz.

O orçamento das despesas alocadas por produto considera gastos com amostras, promoção, propaganda, comissão sobre vendas, brindes, distribuição e testes clínicos realizados após o lançamento do produto. 
As despesas fixas de vendas, de marketing e administrativas são orçadas por centro de responsabilidade. Parte destas últimas, como gastos com edificações, informática, telefonia e recursos humanos, são transferidas para outras áreas, com base em critérios predefinidos de rateio.

A empresa B realiza gastos com pesquisa e desenvolvimento. O seu orçamento é feito por produto.

É elaborado o orçamento de caixa informando, mensalmente, os recebimentos e pagamentos provenientes dos níveis de atividades planejados e do uso dos recursos considerados nos vários orçamentos.

Consolidados os dados, são gerados os relatórios para a tomada de decisões e controle gerencial, a saber: demonstração do resultado, margem de contribuição, demonstrativos de gastos por área e fluxo de caixa.

Essas informações são utilizadas para avaliação e aprovação do orçamento empresarial.

\subsubsection{O controle orçamentário}

O acompanhamento orçamentário é realizado mensalmente, numa reunião formal com a participação do presidente e diretorias. São analisadas as principais variações e definidas ações corretivas visando ao cumprimento dos objetivos gerais da empresa.

Além dessa reunião, há um acompanhamento semanal das vendas por unidades de negócios.

O fluxo de caixa também é controlado semanalmente. 


\subsubsection{Avaliação do processo orçamentário}

De acordo com a avaliação do entrevistado sobre a atenção aos princípios gerais do planejamento, o processo orçamentário é adequado às necessidades. Ver Gráfico 4. A média da nota dasa à aplicação dos princípios gerais de planejamento é 7,9. As menores notas foram atribuídas aos itens “comunicação integral” $(6,5)$ e "reconhecimento do esforço individual e do grupo” $(5,0)$. Porém, os itens “orientação para objetivos” e “aplicação flexível” receberam nota 10,0. O desvio-padrão foi 1,5.

Cabem algumas observações sobre o processo orçamentário da Empresa B. Ele necessita de alguns ajustes, a saber:

- para incrementar a análise por produto, o relatório sobre a margem de contribuição deveria ser calculada para cada produto. Assim, a empresa poderá avaliar o desempenho individual de seus produtos e não somente da unidade de negócios;

- é importante que a empresa recompense o grupo pelos seus esforços em prol do cumprimento dos objetivos;

- questionado sobre o que precisa ser melhorado no item "comunicação integral”, o entrevistado apontou os sistemas de informática utilizados. Na sua opinião, eles necessitam de ajustes estruturais para haver interligação automática de informações. Porém os usuários também necessitam de treinamento. 


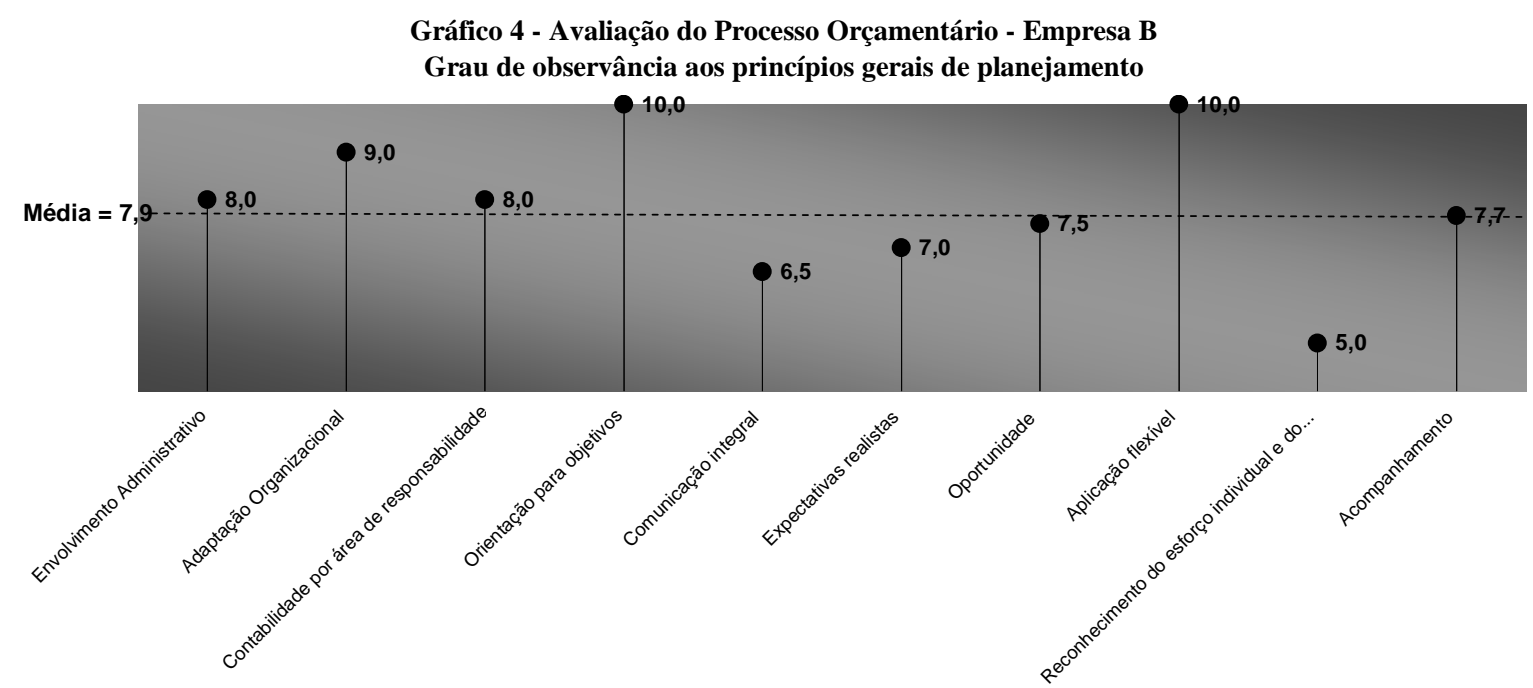

Fonte: A autora

\subsection{EMPRESA C}

\subsubsection{O sistema de informação contábil-gerencial}

O orçamento empresarial, a contabilidade geral e a de custos ficam a cargo da Controladoria na Empresa C. Este setor é responsável, portanto, pelo fornecimento de informações contábil-gerenciais que servirão de apoio aos gestores para a tomada de decisões e controle gerencial.

O sistema de informática encarregado pelo registro, armazenagem, processamento e organização das informações é o Oracle Enterprise Resource Planning - ERP. Um sistema integrado e desempenho suficiente. Adicionalmente, para a elaboração do orçamento empresarial, são utilizadas as planilhas eletrônicas Excel.

No final de cada mês, são emitidos relatórios gerenciais e encaminhados às unidades de negócios e aos gestores dos doze centros de custos em até cinco dias do fechamento contábil. O balanço patrimonial, a demonstração do resultado do exercício, o fluxo de caixa, a margem de contribuição por cliente e por vendedor, o demonstrativo de gastos dos doze 
centros de responsabilidade, indicadores de desempenho e vendas por região e produto. Todos os relatórios contêm o cruzamento das informações realizadas e orçadas e um comparativo entre elas.

Na opinião do entrevistado, o orçamento empresarial é considerado uma ferramenta de apoio às decisões e ao controle gerencial. Percebendo que os demais gestores concordam com essa afirmativa.

\subsubsection{O planejamento}

A empresa realiza processo formal de planejamento que funciona, segundo o gerente financeiro, entrevistado na Empresa C, mas pode ser melhorado.

Com relação ao planejamento de longo prazo, é feita a projeção para cinco anos. São definidas as estratégias gerais, para a empresa, e também para as suas regionais.

Com base nessas estratégias de longo prazo, são definidos os planos de curto prazo. O processo de planejamento tem início em julho do ano anterior e no ano seguinte são realizadas revisões semestrais.

\subsubsection{O orçamento empresarial}

A etapa inicial do processo orçamentário é a definição das premissas, orçamento de investimentos, orçamento de pessoal e estimativa de vendas.

O orçamento de vendas é preparado para cada apresentação de produto. Tanto valores quanto quantidades são utilizadas para medir o desempenho das equipes de vendas.

A empresa não possui fábrica no Brasil. Os produtos são comprados de fábricas do mesmo grupo situadas em outros três países, por isso não prepara orçamento de produção, preocupando-se apenas com o orçamento de compras. O custo dos produtos é determinado pela matriz, incluindo-se os gastos com importação e impostos e o mark-up. 
Despesas com promoção, propaganda, comissões, brindes e fretes são previstas no orçamento de despesas alocadas diretamente aos produtos. As despesas fixas das áreas de vendas, marketing, administrativa e outras são orçadas por centro de custo. Os gastos com informática e recursos humanos são transferidos para as demais áreas.

É elaborado o orçamento anual de caixa visando à administração antecipada de sobras ou insuficiências de dinheiro.

Após a coleta e consolidação dos dados, são elaborados os relatórios listados no item 4.3.1 com dados do orçamento para o ano seguinte comparados com os do ano em curso. Após aprovação, o plano é divulgado para todos os gestores.

\subsubsection{O controle orçamentário}

Caso haja desvios expressivos, o acompanhamento entre real versus orçado é feito mensalmente em reunião formal entre presidente e diretorias. Se o resultado do mês ficar próximo do orçamento, este grupo se reunirá somente a cada três meses.

Para o controle das vendas, o acompanhamento é mensal.

Visando melhor controle do fluxo de caixa, a empresa adotou o procedimento de só efetuar os pagamentos em apenas um dia por semana.

\subsubsection{Avaliação do processo orçamentário}

A nota média das respostas do entrevistado sobre a observação aos princípios gerais de planejamento, apresentada no Gráfico 4, é 8,6, avaliando-se o processo orçamentário da Empresa $\mathrm{C}$ como adequado às necessidades. Verifica-se um desvio-padrão de 1,2, causado pela nota 6,0 atribuída ao item “contabilidade por área de responsabilidade”.

Essa avaliação abaixo da média decorre dos gastos não contabilizados corretamente pela área que os gerou. Ora, se a empresa possui apenas doze centros de responsabilidade e o 
sistema Oracle permite lançamentos por centros de responsabilidade, por que existe esse tipo de problema na empresa? O entrevistado respondeu que muitas compras são efetuadas em conjunto pelas áreas e seus gestores não definem corretamente o critério de rateio, distorcendo a distribuição do gasto. Após o fechamento, detectam o acontecido e pedem vários estornos para ajuste dos gastos por área.

Algumas observações podem ser feitas à Empresa C:

- as informações fornecidas pelo relatório sobre a margem de contribuição poderão ser mais bem aproveitadas se esse for elaborado também por produto e por unidade de negócio.

- para otimizar os lançamentos de gastos por centros de responsabilidades, será necessário um programa de conscientização dos gestores e demais colaboradores que fazem a alocação dos gastos.

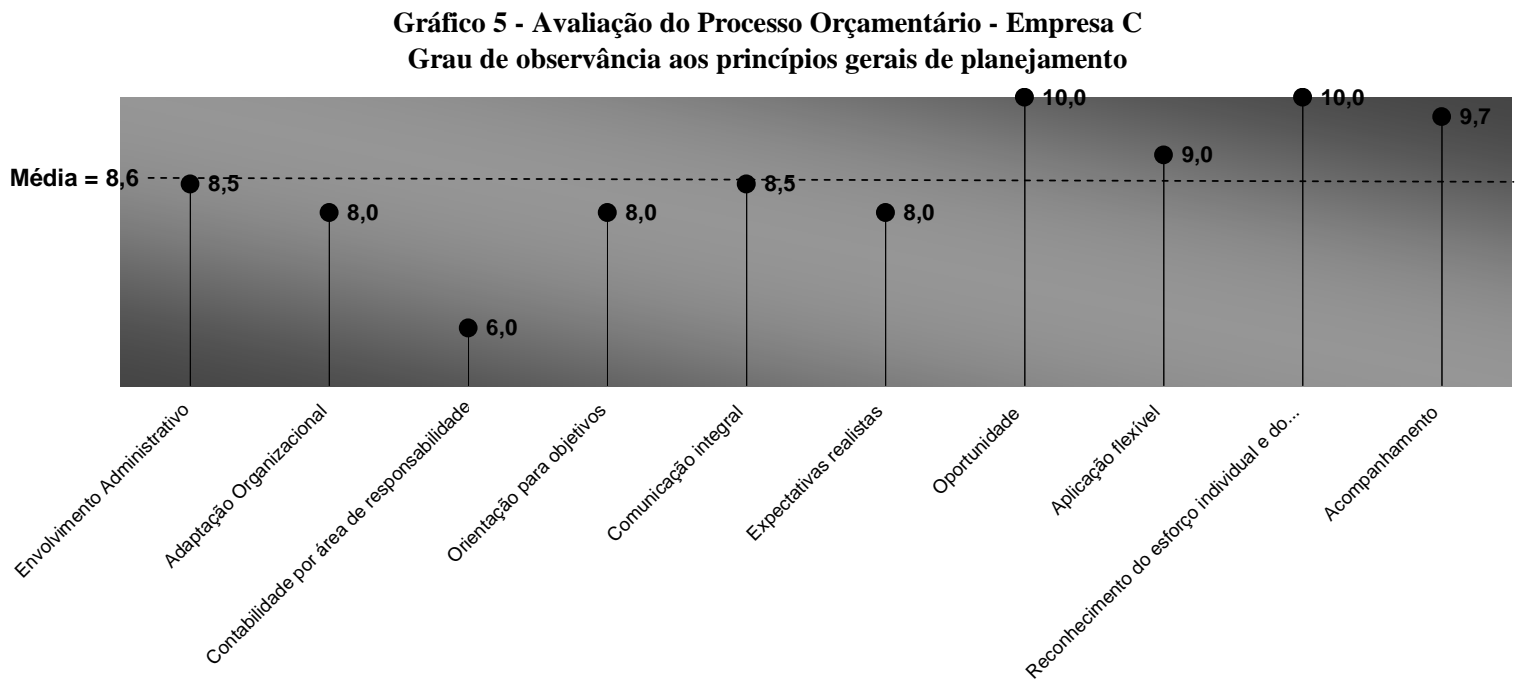

Fonte: A autora 


\subsection{EMPRESA D}

\subsubsection{O sistema de informação contábil-gerencial}

As informações contábil-gerenciais da Empresa D são preparadas pela Controladoria, que desenvolve atividades de contabilidade geral, contabilidade de custos e orçamento empresarial.

O software de gestão utilizado para registrar, armazenar e organizar informações geradas é o Microsiga, sistema brasileiro que processa informações das áreas financeira, contabilidades geral e de custos. O orçamento empresarial e os relatórios para controle gerencial são elaborados com o auxílio do Excel, e as informações realizadas são importadas do primeiro software.

A Controladoria prepara mensalmente as seguintes informações: demonstração do resultado (unidades de negócios e empresa), balanço patrimonial, margem de contribuição (produtos, unidades de negócios e empresa), demonstrativo de gastos por área de responsabilidade, fluxo de caixa, e demonstrativo de impostos. Em todos eles é apresentada uma comparação entre os números realizados e orçados.

O entrevistado, diretor financeiro, informou que todos esses relatórios são efetivamente utilizados pelos demais gestores, exceto o demonstrativo de impostos. Portanto, ele considera que as informações geradas pelo orçamento empresarial são uma ferramenta de apoio às decisões e ao controle gerencial. Ele acredita que os demais gestores corroboram esta opinião.

\subsubsection{O planejamento}

A empresa D possui processo formal de planejamento que inicia no ano anterior e a primeira fase é a definição de estratégias para o longo prazo. 
Um plano anual de negócio estabelece estratégias e ações para o cumprimento dos objetivos de curto prazo e serve de base para a elaboração do orçamento empresarial, que é revisto semestralmente.

\subsubsection{O orçamento empresarial}

Quanto às etapas do processo orçamentário, a definição de premissas financeiras e operacionais marca o início das atividades. A partir desse momento, prepara-se a estimativa de vendas para cada apresentação do produto, a projeção de pessoal e os gastos com investimento em ativo permanente por centro de responsabilidade.

Esta última previsão não é parte de um plano de longo prazo, já que são investimentos pequenos, pois a fábrica, onde esse tipo de gasto é maior, não está situada no Brasil, justifica o entrevistado.

A Empresa D adota projeção contínua de vendas, que é realizada mensalmente para os próximos dezoito meses. Estas informações são servem de base para a avaliação do desempenho da área de vendas.

O custo dos produtos é calculado de acordo com o custo-padrão determinado pela matriz. Como os produtos são comprados fora do país, não há necessidade de se elaborar orçamento de produção. O custo unitário adotado é o custo-padrão acrescido do mark-up, gastos com importação e impostos.

O orçamento de despesas alocadas diretamente aos produtos inclui os seguintes gastos: distribuição de amostras, promoção, propaganda e fretes. Este último é calculado com base num percentual sobre as vendas.

Todas as despesas fixas (vendas, marketing e administrativas) são orçadas por centro de responsabilidade. Não há gastos com pesquisa e desenvolvimento no país. 
O fluxo de caixa é projetado de forma contínua todos os meses para os seis meses seguintes.

Terminada a elaboração do orçamento empresarial, são emitidos os principais relatórios comparados com os números projetados para a finalização do ano anterior.

\subsubsection{O controle orçamentário}

Mensalmente, é realizada uma reunião entre presidência e diretorias visando analisar causas de possíveis desvios entre real e planejado. Para tanto, a Controladoria envia a cada participante os relatórios gerenciais em até cinco dias após o fechamento contábil.

Apesar da reunião formal mensal de controle orçamentário, a Empresa D acompanha diariamente suas vendas.

Para melhorar o controle do caixa, a empresa adotou uma norma estabelecendo o prazo mínimo de cinco dias úteis para que a nota fiscal seja apresentada para pagamento.

\subsubsection{Avaliação do processo orçamentário}

A avaliação apresenta, conforme Gráfico 6, a nota média de 8,4, indicando que os princípios gerais de planejamento são aplicados adequadamente. As notas dadas a tais princípios foram uniformes, com um pequeno desvio-padrão de 0,6, causado basicamente pela avaliação do item “aplicação flexível” com nota 7,0.

Indagado sobre por que esse item recebeu essa nota, o entrevistado esclareceu que, a partir do momento em que o orçamento é aprovado, mesmo havendo as revisões semestrais, pouco se pode alterar.

Cabe lembrar que o orçamento deve ser flexível de forma que as alterações relevantes nos ambientes externo e interno estejam nele refletidas. 


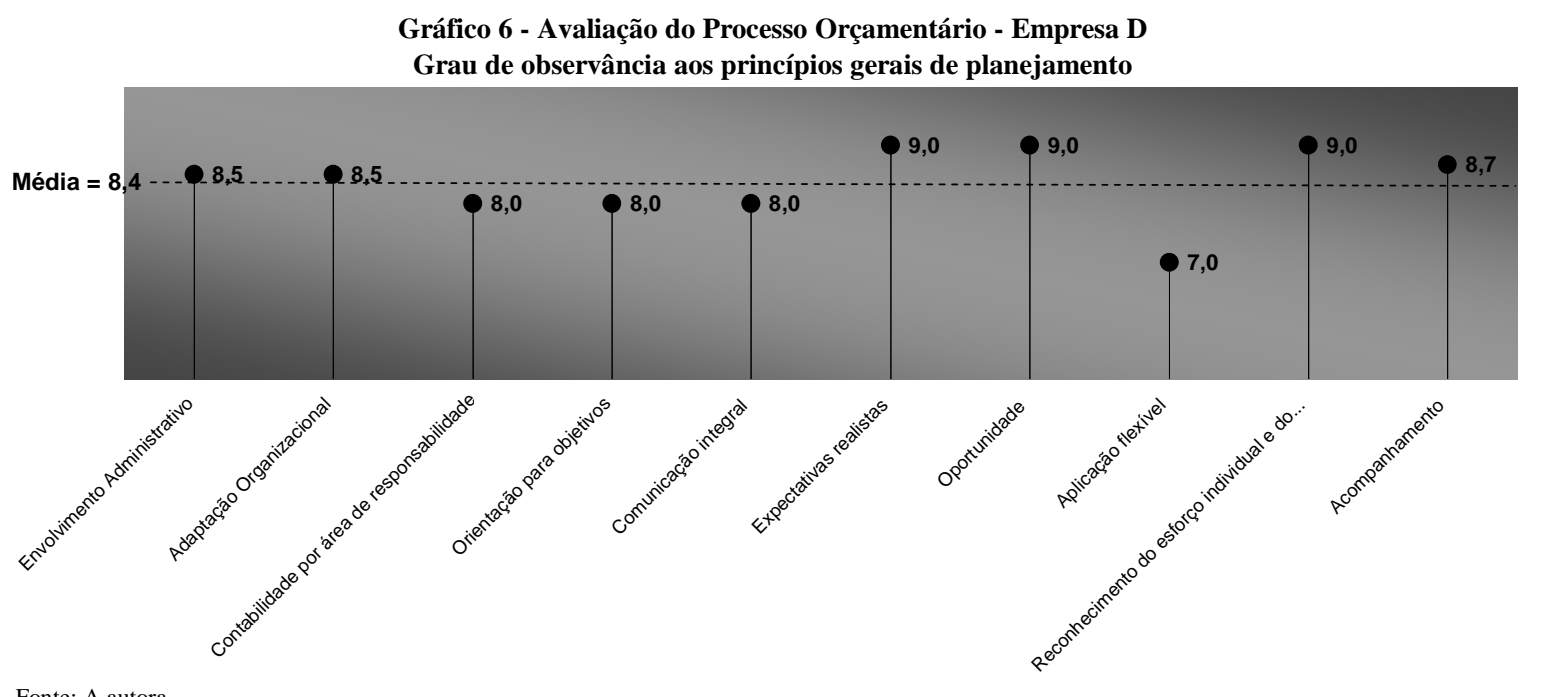

\subsection{EMPRESA E}

\subsubsection{O sistema de informação contábil-gerencial}

As atividades de contabilidade geral, contabilidade de custos e orçamento empresarial da Empresa E são realizadas pela Controladoria. A responsabilidade pelo fornecimento de informações contábil-gerenciais é do diretor administrativo-financeiro, que foi o entrevistado nesta empresa.

O sistema de gestão adotado é o da empresa americana QAD, o MFG/PRO-ERP (Enterprise Resource Planning), um aplicativo que faz a integração das informações geradas por todos os processos da empresa. No entanto, para as atividades do orçamento empresarial, o software utilizado é o Excel, da Microsoft, que recebe do MFG/PRO os números já contabilizados.

Na opinião do entrevistado, estes sistemas são bons e atendem relativamente bem às necessidades, mas a transferência dos números do QAD para o Excel, que não é feita via cargas de tabelas, ainda gera re-trabalho. 
Os relatórios expedidos pela Controladoria são a demonstração do resultado (unidade de negócios e empresa), balanço patrimonial, margem de contribuição (produto, unidade de negócios e empresa), gastos por centro de responsabilidade, fluxo de caixa e BSC (Balanced Scorecard). Todos são utilizados pelos demais gestores, já que informam os números realizados, orçamento e um comparativo entre eles.

O entrevistado afirma que o orçamento empresarial é uma ferramenta de apoio à tomada de decisão e ao controle gerencial.

\subsubsection{O planejamento}

A Empresa E elabora plano de resultado de longo prazo em que define estratégias para cumprimento dos seus objetivos gerais de longo prazo.

Anualmente, com base nesse plano, a empresa estabelece estratégias de curto prazo, formalizadas no plano anual de negócios.

O orçamento empresarial, cujo processamento tem início no ano anterior, é o reflexo financeiro deste plano de curto prazo.

\subsubsection{O orçamento empresarial}

O processo orçamentário tem início com as etapas de estabelecimento de premissas, projeção de investimento, pessoal e vendas. Para esta última, a empresa mantém projeção contínua, visando maior acurácia do volume estimado.

Sobre as estimativas de investimento e de pessoal, são calculados os gastos com depreciação e pessoal, respectivamente. O orçamento de vendas é calculado com base na estimativa de vendas, por apresentação do produto. 
A maioria de seus produtos é fabricada internamente e seu custo é projetado pela fábrica com a área de custos. Outra parte é comprada da matriz ou de terceiros. Nestes casos são acrescentados ao custo de aquisição os gastos com importação, impostos, mark-up e frete.

No orçamento dos gastos alocados diretamente aos produtos são inclusas despesas com promoção, propaganda, comissões, distribuição de amostras e gastos com royalties.

As despesas fixas com a força de vendas, marketing e administração são orçadas por centro de responsabilidade. Os gastos com telefone e treinamento são alocados diretamente à área solicitante. Os gastos com limpeza, manutenção de software e aluguel são distribuídos com base em critérios de rateios.

A empresa elabora o orçamento anual de caixa cuja projeção é atualizada continuamente.

Ao final do processo orçamentário, são elaborados os relatórios que servirão de base para avaliação da proposta que, depois de aprovada, é divulgada para alguns gestores.

\subsubsection{O controle orçamentário}

A empresa E acompanha quinzenalmente seus resultados. Para tanto é realizada reunião formal com presidente e diretores.

Visando ao cumprimento do orçamento de caixa, a empresa estabeleceu o prazo mínimo de dez dias para o envio das notas fiscais pelas áreas para pagamento.

\subsubsection{Avaliação do processo orçamentário}

No Gráfico 7 apresentam-se as notas da avaliação feitas pelo entrevistado sobre a observância dos princípios gerais de planejamento. A nota média foi 7,3, a mais baixa de todas as empresas. 
Assim, de acordo com a escala de avaliação constante da Tabela 2, o processo orçamentário pode ser classificado como relativamente adequado.

Esta média foi influenciada pelos itens “orientação para objetivos”, “comunicação integral” e “aplicação flexível”, que obtiveram nota 6,0, e os itens “expectativas realistas” e “oportunidade”, com nota 7,0. Na opinião do entrevistado esses itens são observados, mas ainda precisam ser melhorados.

Os principais pontos de melhora apontados pelo entrevistado são:

- Algumas metas não estão apoiadas em expectativas realistas.

- Nem todos os colaboradores responsáveis pelo cumprimento dos objetivos são envolvidos no processo orçamentário. Parte deles sequer recebe as informações sobre o orçamento aprovado.

- Algumas modificações ocorridas no ambiente externo não são refletidas nas revisões orçamentárias.

- O sistema de informática adotado necessita de ajustes para atender as necessidades dos usuários.

- Após o fechamento mensal, a empresa ainda possui certa dificuldade em gerar os relatórios para análise e controle em até cinco dias úteis. 


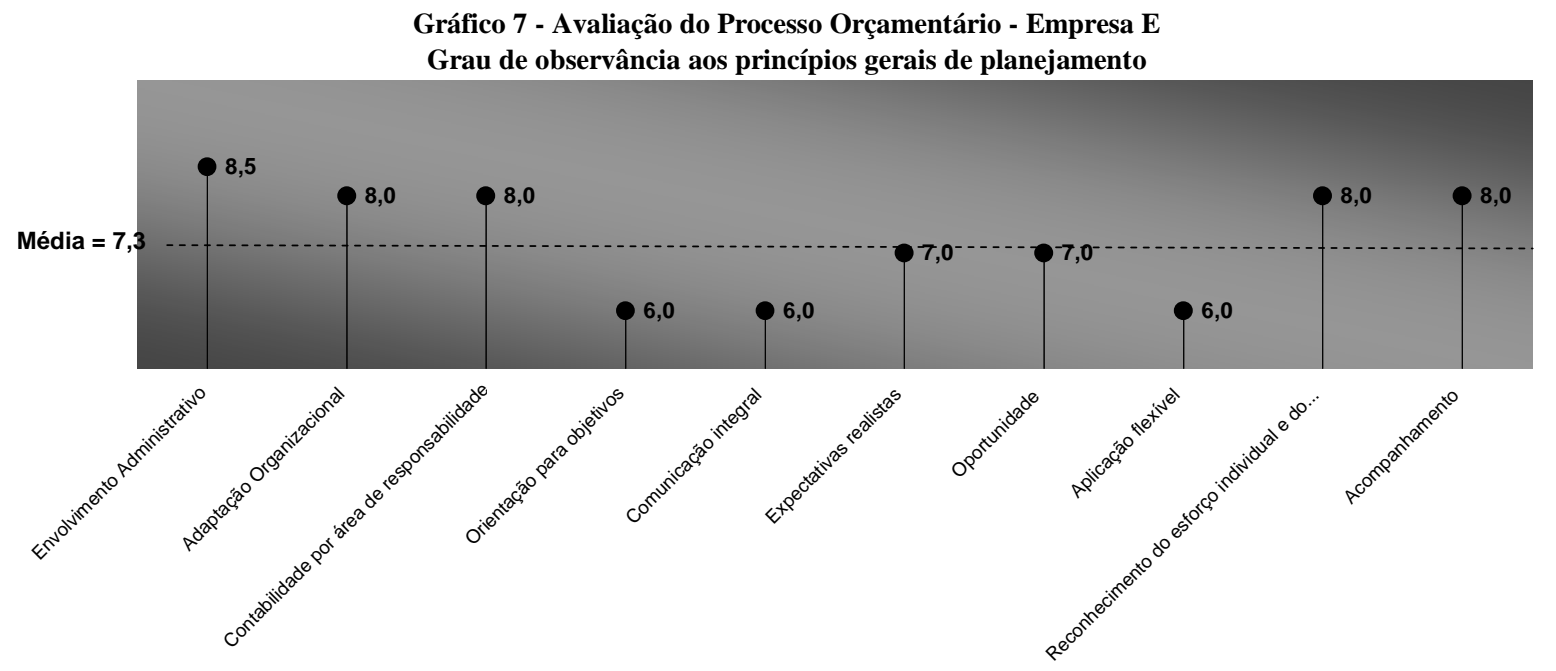

Fonte: A autora

\subsection{VISÃO GERAL DAS EMPRESAS}

\subsubsection{O sistema de informação contábil-gerencial}

As cinco empresas entrevistadas possuem área de Controladoria ou assemelhada que executa atividades de planejamento, controle, contabilidade geral e de custos. Esta área também responde pelo fornecimento de informações contábil-gerenciais aos demais gestores.

Os sistemas de informática utilizados para armazenar, processar e consolidar as informações contábeis e financeiras podem ser considerados relativamente adequados às necessidades. Precisam de ajustes técnicos e seus usuários devem estar aptos a operá-los.

Todas as empresas elaboram anualmente o orçamento empresarial.

Os entrevistados consideram o orçamento empresarial uma ferramenta de apoio à tomada de decisões e ao controle gerencial e percebem que os demais gestores corroboram esta afirmativa. 


\subsubsection{O planejamento}

A maioria das empresas possui planejamento formal de atividades, definem e revisam anualmente estratégias de ações para o longo prazo e curto prazo. A Empresa A não realiza planejamento de longo prazo.

Os entrevistados das Empresas B, C e D reconhecem que o processo de planejamento adotado necessita de ajustes.

\subsubsection{O orçamento empresarial}

As etapas do processo orçamentário sugeridas no Capítulo 2, item 2.3 .3 são executadas praticamente em todas as empresas.

A projeção contínua das vendas é elaborada por todas elas, exceto pela Empresa B, que pretende implantá-la. As Empresas B e C não fazem esta projeção no grau máximo de detalhamento (por forma de apresentação de cada produto). A primeira faz somente por unidade de negócios e a segunda, por produto (brand).

Com relação ao orçamento de investimentos baseado num plano de longo prazo, a Empresa D justifica que não há necessidade, pois, como a empresa não possui fábrica no Brasil, os investimentos são pequenos.

A Empresa A não coleta as informações sobre movimentação de pessoal anteriormente ao cálculo das despesas com pessoal, a justificativa é que são raras as alterações.

Parte das despesas gerais e administrativas é transferida para as áreas que utilizam o serviço em todas as empresas com exceção da Empresa D que optou por mantê-las em um único centro de responsabilidade.

Quanto aos relatórios para análise global do orçamento como as projeções da demonstração do resultado, a margem de contribuição e os gastos por área são gerados por 
todas as cinco empresas. O balanço patrimonial é projetado somente nas Empresas C e D. A Empresa A não elabora projeção do fluxo de caixa.

Após aprovação, os relatórios gerados com informações do orçamento são divulgados para os respectivos gestores. Vale salientar que, nas Empresas B e E, nem todos os responsáveis recebem seu orçamento, indicando que este procedimento ainda pode ser melhorado.

\subsubsection{O controle orçamentário}

Todas as empresas realizam reunião formal, geralmente mensal, para acompanhamento dos resultados.

Nessa reunião, em que participam o presidente e as diretorias, utilizando informações contábil-gerenciais, os gestores procuram justificar eventuais variações entre os números realizados e orçados. A partir daí tomam novas decisões objetivando o cumprimento dos objetivos gerais da empresa.

\subsubsection{Avaliação do processo orçamentário}

As cinco empresas receberam uma nota média de 8,1 indicando que possuem um processo orçamentário adequado às necessidades, conforme proposta de avaliação na Tabela

2. O desvio padrão é apenas 0,5 , causado basicamente pela variação entre as médias 7,3 da Empresa E e 8,6 da Empresa C.

Analisando as notas médias dadas a cada um dos princípios gerais do planejamento, observa-se que os princípios “orientação para objetivos”, “comunicação integral” e “aplicação flexível” receberam as menores notas, 6,0, que estão bem abaixo da média geral 8,1. Também ficaram abaixo as médias das notas dos princípios "expectativas realistas” e "oportunidade”, com nota 7,0. 


\section{Gráfico 8 - Avaliação do Processo Orçamentário} Nota Média por Empresa

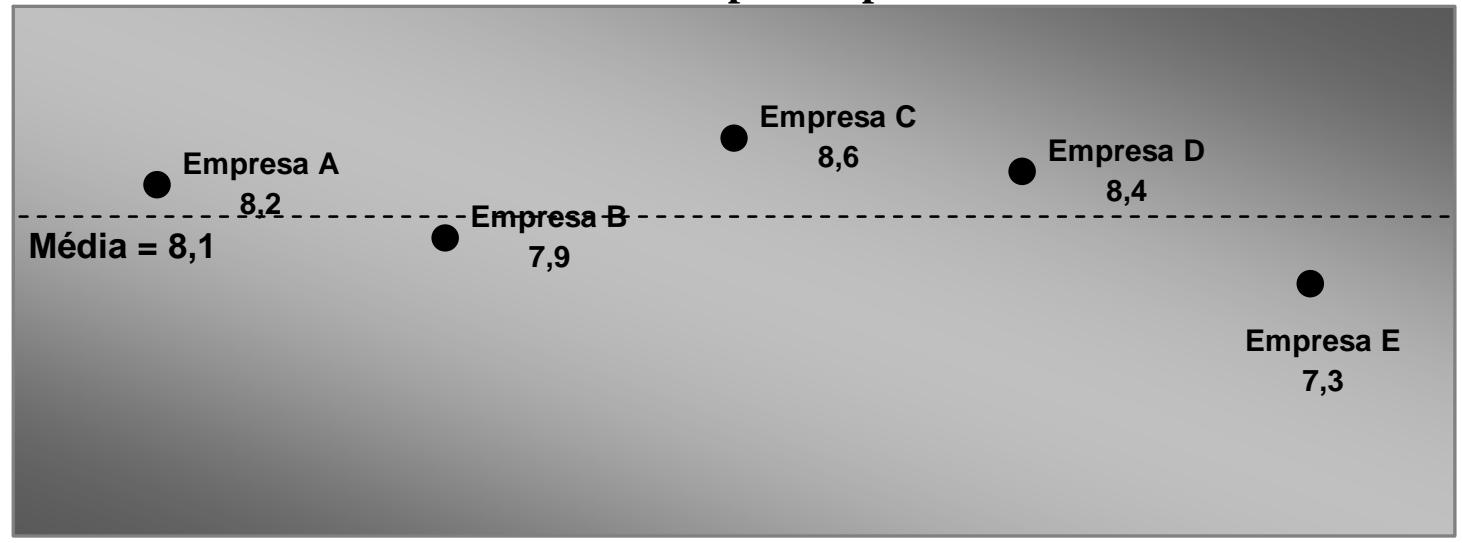

Fonte: A autora

Assim, corroborando a opinião de alguns dos entrevistados, apesar de as empresas contarem com um processo orçamentário adequado às necessidades, observa-se que ainda há pontos que podem ser melhorados. Tais como “comunicação integral”, que inclui melhoria do desempenho e utilização do sistema de informática, e "reconhecimento do esforço individual e do grupo".

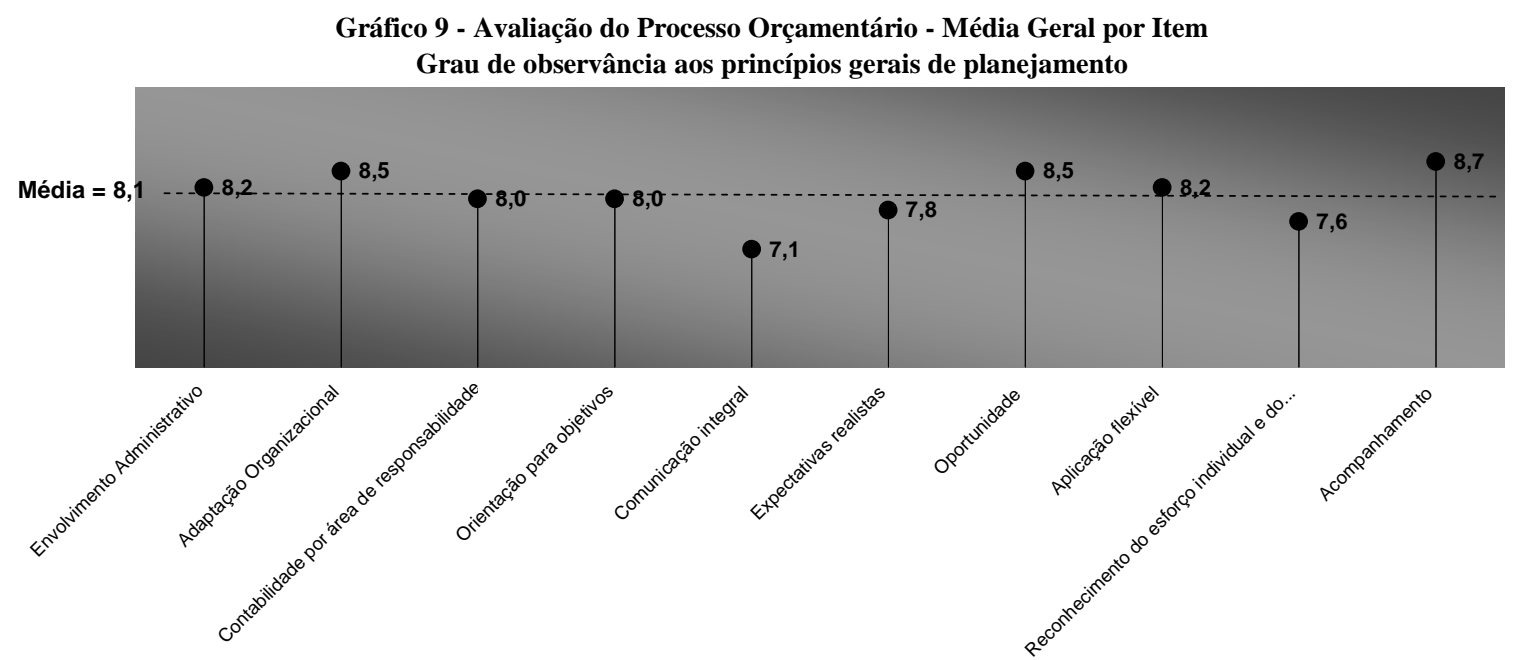

Fonte: A autora 


\section{CONCLUSÃO E RECOMENDAÇÕES}

A acirrada competição global e as constantes intervenções e regulamentações governamentais vêm exigindo das indústrias farmacêuticas a adoção de estratégias para manutenção de seus clientes e para vencer a concorrência.

No caso das indústrias de médio porte, a situação é ainda mais grave, pois precisam sobreviver em meio às gigantes do setor.

O sucesso dessas indústrias farmacêuticas de médio porte está fortemente atrelado não somente à boa gestão, mas também às ferramentas que seus gestores utilizam para auxiliá-los nessa tarefa.

Nesse contexto, nesta dissertação buscou-se verificar se o orçamento empresarial é utilizado pelas indústrias farmacêuticas de médio porte e se é considerado uma ferramenta de apoio à tomada de decisões e ao controle gerencial.

Para dar suporte ao estudo, foi realizada ampla e completa revisão teórica, objetivando-se analisar os conceitos, princípios, processo de elaboração, vantagens e limitações que envolvem o orçamento empresarial.

Não foram elaboradas hipóteses a serem testadas nos estudos de casos por se tratar de um estudo exploratório. A pesquisa restringiu-se à busca de informações. Para tanto, como metodologia de pesquisa, foi adotado o estudo de caso múltiplo, em que se entrevistaram os gestores financeiros de cinco empresas farmacêuticas de médio porte.

Como instrumento de coleta de dados, foram feitas entrevistas roteirizadas com cada empresa, levadas a efeito pela própria pesquisadora, quando se obtiveram informações sobre o sistema de informações contábil-gerencial, sobre a estrutura de planejamento dos resultados em curto e longo prazos, sobre o modelo aplicado na elaboração do orçamento empresarial e sobre a opinião dos gestores sobre a adequação do processo orçamentário adotado. 
Os entrevistados foram unânimes em afirmar que o orçamento empresarial é utilizado como ferramenta de apoio às decisões e ao controle gerencial.

Observou-se, também, que todas as cinco empresas possuem área estruturada com o objetivo de fornecer informações contábil-gerenciais aos gestores, que as utilizam para a tomada de decisão e o controle gerencial. Para tanto é responsável pelo orçamento empresarial, contabilidade geral e de custos. Todas as empresas contam com sistema de informática adequado às necessidades, mas, em algumas, ainda pode ser melhorado.

A maioria das empresas adota estrutura formal para planejamento dos resultados em curto e longo prazos, quando definem as estratégias de ação para o cumprimento dos objetivos gerais. Esses planejamentos são a base para a elaboração do orçamento empresarial.

Quanto ao modelo aplicado, as empresas observam as etapas sugeridas no Capítulo 2 desta dissertação para a elaboração do orçamento empresarial, incluindo-se as etapas operacionais e financeiras.

Na avaliação dos entrevistados, sobre a observação aos princípios gerais do planejamento, o processo orçamentário adotado é adequado às necessidades em quase todas as empresas, exceto na Empresa E em que foi avaliado como relativamente adequado. Apesar dessa avaliação positiva, os entrevistados salientaram que ainda há pontos a serem melhorados, justificando a nota média 8,1, apresentada no Gráfico 8. Os itens que receberam as menores notas foram “comunicação integral” e "reconhecimento do esforço individual e em grupo”, conforme se vê no Gráfico 9.

Conclui-se, portanto, que o orçamento empresarial é utilizado pelos gestores entrevistados como ferramenta de apoio às decisões e ao controle gerencial. Entretanto alguns ajustes podem ser feitos visando otimizar os seus benefícios.

Deve-se ressaltar, novamente, que a escolha do estudo de casos múltiplos como técnica de pesquisa não permite a generalização dos resultados obtidos nesta pesquisa. Além 
disso, vale salientar que pode ter ocorrido um possível viés por parte dos gestores entrevistados objetivando dar valor ao seu trabalho. Esta observação pode ter sido amenizada pelo conhecimento das práticas orçamentárias por parte da pesquisadora, sem, contudo, eliminar possíveis desvios de percepção.

Este estudo proporcionou conhecimento sobre o sistema de informação contábilgerencial e, principalmente, sobre o uso do orçamento empresarial como ferramenta de apoio à gestão em empresas fechadas e de difícil acesso às informações contábeis e financeiras.

Visando à contribuição para novos estudos, vale destacar que todas as empresas pesquisadas pertencem a grupos estrangeiros, que exigem elevado grau de planejamento e controle. Assim, sugere-se estudo semelhante com empresas de origem brasileira e pertencentes a outros setores, em que pode não haver processo formal de planejamento nem a elaboração de orçamento empresarial. 


\section{$\underline{\text { REFERÊNCIAS }}$}

ACKOFF, R.; FINNEL, E. V.; GHARAJEDAGHI, J. et al. A guide to controlling your corporation's future. New York: John Wiley, 1984.

AXSON, D. A. J. Best Practices in Planning and Management Reporting: from data to decisions. New Jersey: Wiley, 2003.

ANTHONY, R. N.; GOVINDARAJAN, V. Sistemas de Controle Gerencial. São Paulo: Atlas, 2001.

ATHAR, M. In Handbook of Budgeting. $3^{\text {rd }}$ edition. New York: Wiley, 1998

BEDÊ, M. A. Coordenador. Sobrevivência e mortalidade das empresas paulistas de 1 a 5 anos. São Paulo: Sebrae, 2005.

BNDES: Banco Nacional de Desenvolvimento Econômico e Social; http://www.bndes.gov.br/empresa/default.asp

PEARCE, L. M. Business Plans Handbook: a compilation of actual business plans developed by businesses throughout North America. Volume 10, Detroit: Thomson Gale, c2004.

CASSARRO, A. C. Sistemas de informações para tomada de decisões. 3. ed. São Paulo: Pioneira Thomson, 2003.

CAMARGOS, M. A.; DIAS, A. T. Estratégia, Administração Estratégica e Estratégia Corporativa: uma síntese teórica. Caderno de Pesquisas em Administração, São Paulo, v. 10, no. 1, janeiro/março 2003.

COLLIS, J.; HUSSEY, R. Pesquisa em Administração: um guia prático para alunos de graduação e pós-graduação. Trad. Lucia Simonini. 2. ed. São Paulo: Bookman, 2005. 
COOPER, D. R.; SCHINDLER, P.S. Métodos dePesquisa em Administração. Trad. Luciana de Oliveira da Rocha. 7. ed. Porto Alegre: Bookman, 2003.

DELLOITE Consultoria. As Pequenas e Médias Empresas que mais Crescem no Brasil: uma pesquisa sobre visões e práticas que aceleram o ritmo de expansão dos negócios. 2007. Divulgado no site www.delloite.com.br

FEBRAFARMA, Federação Brasileira da Indústria Farmacêutica. A indústria farmacêutica no Brasil: uma contribuição para as políticas públicas. (wwww.frebrafarma.org.br, acessado em 10.08.2007).

FIGUEIREDO, S.; CAGGIANO, P.C. Controladoria: teoria e prática. 3. ed. São Paulo: Atlas, 2004.

FISCHMANN, A. A.; ALMEIDA, M. I. R. Planejamento Estratégico na Prática. 2. ed. São Plaulo: Atlas, 1991.

FREZATTI, F. Orçamento Empresarial: planejamento e controle gerencial. 3. edição. São Paulo: Atlas, 2006.

KOTLER, P. Administração de marketing: a edição do novo milênio. Tradução de Bazán Tecnologia e Lingüística. São Paulo: Prentice Hall, 2000.

KRUEGER, C. A. In Corporate Controller's Manual. 2nd edition. Warren, Gorham \& Lamont, 1998.

MARCONI, M. A.; LAKATOS, E. M. Fundamentos de Metodologia Científica. 6. ed. São Paulo: Atlas, 2006.

MATTAR, F. N. Pesquisa de marketing: metodologia, planejamento. Volume 1. 4. ed. São Paulo: Atlas: 1997.

MOREIRA, J. C. Coordenador. Orçamento Empresarial: manual de elaboração. 5. edição. São Paulo: 2002 
OLIVEIRA, D. P. R. de. Planejamento Estratégico: conceitos, metodologia e práticas. 22. ed. São Paulo: Atlas, 2005

PASSARELLI, J.; BOMFIM, E. A. Orçamento Empresarial: como elaborar e analisar. São Paulo: IOB-Thomson, 2004.

PEREIRA, J. C. R. Análise de Dados Qualitativos: estratégias metodológicas para as ciências da saúde, humanas e sociais. 2. ed. São Paulo: Editora da Universidade de São Paulo, 1999.

RACHLIN, R. Handbook of Budgeting. 3· edition. New York: Wiley, 1993

ROMANO, L. A. N.; PELAJO, M. A.; SILVA, M. A. C. Análise de Desempenho Econômicofinanceiro do Setor Farmacêutico no Brasil de 2003 a 2005. São Paulo: Febrafarma, 2007.

SCHWARTZ, G. Science in marketing. New York: John Wiley, 1970.

TUNG, N.H. Orçamento Empresarial e Custo Padrão. 4. ed. São Paulo: Edições Universidade-Empresa, 1994.

VOGT , W.P. Dictionary of Statistics and Methodology. Newbury Park: Sage, 1993.

YIN, R. K. Estudo de Caso: planejamento e métodos. Trad. Daniel Grassi. 3. ed. Porto Alegre: Bookman, 2005.

YOO, W. S. An information-bases decision making framework for evaluating and forecasting a project cost and completion date. Dissertation. The Ohio State University, 2007. Finding in: proquest research.

http://proquest.umi.com/pqdweb?index $=0 \&$ sid=2\&srchmode $=1 \& v i n s t=P R O D \& f m t=2 \&$ startp age $=1 \&$ clientid=61611\&vname $=$ PQD $\&$ RQT $=309 \&$ did=1390304421\&scaling $=$ FULL\&ts $=12$ $12340608 \& v$ type $=$ PQD\&rqt $=309 \& T S=1212340617 \&$ clientId $=61611 \& \mathrm{cc}=1 \& \mathrm{TS}=121234061$ $\underline{7}$, access in June $1^{\text {st }}, 2008$. 
WELSCH, G. A. Orçamento Empresarial. Trad. de Antônio Zoratto Sanvicente. 5. ed. São Paulo: Atlas, 1994.

WENDELL, P. J. Editor. Corporate Controller's Manual. 2nd edition. Warren, Gorham \& Lamont, 1998. 


\section{ANEXOS}

I. Ranking de Laboratórios - Grupemef

II. Estrutura do formulário utilizado nas entrevistas (roteiro). 
ANEXO I - RANKING DOS 200 MAIORES LABORATÓRIOS FARMACÊUTICOS NO BRASIL - POR FATURAMENTO - JULHO/2007 . GRUPEMEF

\begin{tabular}{|c|c|c|}
\hline RANKING & SIGLA & LABORATÓRIO \\
\hline 1 & E3S & EMS SIGMA PHARMA \\
\hline 2 & $\bar{S}$ S_A & SANOFI-AVENTIS \\
\hline 3 & $\mathrm{~A} 4 \mathrm{H}$ & ACHE \\
\hline 4 & MD7 & MEDLEY \\
\hline 5 & NVR & NOVARTIS \\
\hline 6 & PFZ & PFIZER \\
\hline 7 & EUF & EUROFARMA \\
\hline 8 & B_I & BOEHRINGER ING \\
\hline 9 & SHG & SCHERING DO BRASIL \\
\hline 10 & J_C & JANSSEN CILAG \\
\hline 11 & AAA & ALTANA PHARMA LTDA \\
\hline 12 & DNF & D M IND.FTCA \\
\hline 13 & $\mathrm{ROC}$ & ROCHE \\
\hline 14 & MQF & MANTECORP I Q FARM \\
\hline 15 & BAY & BAYER \\
\hline 16 & AZN & ASTRAZENECA BRASIL \\
\hline 17 & BS2 & BIOLAB-SANUS FARMA \\
\hline 18 & MSD & MERCK SHARP DOHME \\
\hline 19 & BMS & BRISTOL MYER SQUIB \\
\hline 20 & MCK & MERCK \\
\hline 21 & GSK & GLAXOSMITHKLINE \\
\hline 22 & LIB & LIBBS \\
\hline 23 & $\mathrm{ABT}$ & ABBOTT \\
\hline 24 & LLY & LILLY \\
\hline 25 & ALC & ALCON \\
\hline 26 & GKC & GSK CONSUMO \\
\hline 27 & ORG & ORGANON \\
\hline 28 & FAS & FARMASA \\
\hline 29 & U_Q & UNIAO QUIMICA F N \\
\hline 30 & PRG & PROCTER GAMBLE \\
\hline 31 & WYE & WYETH \\
\hline 32 & SDZ & SANDOZ DO BRASIL \\
\hline 33 & APS & APSEN \\
\hline 34 & $\overline{\text { STF }}$ & STIEFEL \\
\hline 35 & ALL & ALLERGAN \\
\hline 36 & FQM & FARMOQUIMICA \\
\hline 37 & SHC & SCHERING PLOUGH \\
\hline 38 & N_Q & NEO QUIMICA \\
\hline 39 & MJA & MARJAN \\
\hline 40 & J_J & JOHNSON JOHNSON \\
\hline 41 & GLD & GALDERMA \\
\hline 42 & WHH & WHITEHALL \\
\hline 43 & SVR & SERVIER DO BRASIL \\
\hline 44 & NV0 & NOVARTIS CONSUMER \\
\hline 45 & SVY & SOLVAY FARMA \\
\hline 46 & TNT & TORRENT \\
\hline 47 & ZAM & ZAMBON \\
\hline 48 & LRP & LA ROCHE POSAY \\
\hline
\end{tabular}


ANEXO I - RANKING DOS 200 MAIORES LABORATÓRIOS FARMACÊUTICOS NO BRASIL - POR FATURAMENTO - JULHO/2007 .

GRUPEMEF

\begin{tabular}{|c|c|c|}
\hline RANKING & SIGLA & LABORATÓRIO \\
\hline 49 & TTB & TEUTO BRASILEIRO \\
\hline 50 & $\overline{B A L}$ & BALDACCI \\
\hline 51 & CF2 & CIFARMA \\
\hline 52 & $\mathrm{N \_ N}$ & NOVO NORDISK \\
\hline 53 & CT6 & CRISTALIA \\
\hline 54 & LUN & LUNDBECK \\
\hline 55 & F_I & FARMALAB IQF \\
\hline 56 & IGF & IGEFARMA \\
\hline 57 & RBY & RANBAXY \\
\hline 58 & $\overline{D C S}$ & DAIICHI SANKYO \\
\hline 59 & HBR & HEBRON \\
\hline 60 & $\mathrm{NKO}$ & NIKKHO \\
\hline 61 & CM5 & CIMED \\
\hline 62 & BHL & BAUSCH LOMB \\
\hline 63 & VLT & VALEANT FARMACEUTI \\
\hline 64 & ZD1 & ZODIAC \\
\hline 65 & NES & NESTLE \\
\hline 66 & UCI & UCI FARMA \\
\hline 67 & SER & SERONO \\
\hline 68 & GM2 & GERMED \\
\hline 69 & MLL & MILLET ROUX \\
\hline 70 & GRO & GROSS \\
\hline 71 & $\mathrm{IS}_{-}$ & INTENDIS \\
\hline 72 & $\overline{\mathrm{MPH}}$ & MEPHA \\
\hline 73 & BF8 & BRAINFARMA \\
\hline 74 & CAT & CATARINENSE \\
\hline 75 & CNN & CANONNE \\
\hline 76 & $\mathrm{AT}_{-}$ & ATIVUS \\
\hline 77 & D_O & DAUDT OLIVEIRA \\
\hline 78 & C_P & COLGATE \\
\hline 79 & ZUR & ZURITA \\
\hline 80 & FC2 & FARMACO \\
\hline 81 & $\overline{B \_Y}$ & BIOMY \\
\hline 82 & HSM & HISAMITSU \\
\hline 83 & LR3 & LUPER \\
\hline 84 & MB9 & MULTILAB \\
\hline 85 & GMK & GLENMARK \\
\hline 86 & BLF & BELFAR \\
\hline 87 & BNK & BUNKER \\
\hline 88 & $\overline{G \_G}$ & GALENOGAL \\
\hline 89 & VCY & VICHY \\
\hline
\end{tabular}


ANEXO I - RANKING DOS 200 MAIORES LABORATÓRIOS FARMACÊUTICOS NO BRASIL - POR FATURAMENTO - JULHO/2007 .

GRUPEMEF

\begin{tabular}{|c|c|c|}
\hline RANKING & SIGLA & LABORATÓRIO \\
\hline 90 & HTZ & HERTZ \\
\hline 91 & EVR & EVERSIL \\
\hline 92 & HBA & HERBARIUM \\
\hline 93 & SN2 & SANIPLAN \\
\hline 94 & $\overline{\mathrm{BAG}}$ & BAGO \\
\hline 95 & L3F & LATINOFARMA \\
\hline 96 & MDQ & MEDQUIMICA \\
\hline 97 & DLT & DELTA \\
\hline 98 & GLO & GLOBO \\
\hline 99 & DRW & DARROW \\
\hline 100 & MIN & MINANCORA \\
\hline 101 & P7B & PHARLAB \\
\hline 102 & VTM & VITAMED \\
\hline 103 & TPQ & TRB \\
\hline 104 & GRA & GRANADO \\
\hline 105 & DFP & DIFFUCAP-CHEMOBRAS \\
\hline 106 & SSP & SUPPORT \\
\hline 107 & P_F & PIERRE FABRE \\
\hline 108 & LG6 & LEGRAND \\
\hline 109 & BUG & BLAUSIEGEL \\
\hline 110 & PLB & PHARMASCIENCE LAB \\
\hline 111 & O_M & OSORIO MORAES \\
\hline 112 & FER & FERRING \\
\hline 113 & IRA & INFABRA \\
\hline 114 & WES & WESP \\
\hline 115 & BAR & BARUEL \\
\hline 116 & $\mathrm{MP}_{-}$ & MELPOEJO \\
\hline 117 & BRT & BRASTERAPICA \\
\hline 118 & VEP & VE PE \\
\hline 119 & SVS & SILVESTRE \\
\hline 120 & $\mathrm{HBF}$ & H.B.FARMA \\
\hline 121 & GYR & GEYER \\
\hline 122 & ELO & ELOFAR \\
\hline 123 & $\mathrm{COE}$ & COMBE \\
\hline 124 & MKR & MAKROFARMA \\
\hline 125 & SIN & SINTERAPICO \\
\hline 126 & DUC & DUCTO \\
\hline 127 & NNN & NOVARTIS NUTRITION \\
\hline 128 & MIA & MILIAN \\
\hline 129 & $\overline{\mathrm{BNU}}$ & BIONATUS \\
\hline 130 & G7L & GALLIA \\
\hline
\end{tabular}


ANEXO I - RANKING DOS 200 MAIORES LABORATÓRIOS FARMACÊUTICOS NO BRASIL - POR FATURAMENTO - JULHO/2007 .

GRUPEMEF

\begin{tabular}{|c|c|c|}
\hline RANKING & SIGLA & LABORATÓRIO \\
\hline 131 & ROY & ROYTON \\
\hline 132 & ZYD & ZYDUS \\
\hline 133 & CLX & CLIMAX \\
\hline 134 & VAP & VITAPAN \\
\hline 135 & HEP & HEPACHOLAN \\
\hline 136 & GOB & GEOLAB \\
\hline 137 & MLR & MELORA DERME \\
\hline 138 & WPR & WALDEMIRO PEREIRA \\
\hline 139 & NCK & NECKERMAN \\
\hline 140 & AW4 & ARROW FARMACEUTICA \\
\hline 141 & NNA & NUTRILATINA \\
\hline 142 & BEM & BERGAMO \\
\hline 143 & MIZ & MEIZLER \\
\hline 144 & I_B & BIOCHIMICO \\
\hline 145 & SNV & SANVAL \\
\hline 146 & SUV & SUNDOWN \\
\hline 147 & BEI & BEIERSDORF \\
\hline 148 & B_A & BETA ATALAIA \\
\hline 149 & $\overline{\mathrm{CAZ}}$ & CAZI \\
\hline 150 & FAY & FARMAVY \\
\hline 151 & GP8 & GREEN PHARMA \\
\hline 152 & H6B & HERBORISA \\
\hline 153 & QUS & QUIMSUL \\
\hline 154 & Q_B & QUIMICA BIOLOGIA \\
\hline 155 & REU & REGIUS \\
\hline 156 & SDP & SIDEPAL \\
\hline 157 & TKS & T K S FARMACEUTICA \\
\hline 158 & ZLB & ZLB BEHRING \\
\hline 159 & $\mathrm{HPO}$ & HIPOLABOR \\
\hline 160 & FON & FONTOVIT \\
\hline 161 & KIN & KINDER \\
\hline 162 & CLR & CELLOFARM \\
\hline 163 & BMI & BIOMEDICA \\
\hline 164 & PNU & PRONATU \\
\hline 165 & MAV & MADREVITA \\
\hline 166 & MIR & MILLER \\
\hline 167 & C6R & CARESSE \\
\hline 168 & BSS & BALLDARASSI \\
\hline 169 & GOU & GOULART \\
\hline 170 & PRF & PROFARMIG \\
\hline 171 & BFR & BIOFARMA \\
\hline
\end{tabular}


ANEXO I - RANKING DOS 200 MAIORES LABORATÓRIOS FARMACÊUTICOS NO BRASIL - POR FATURAMENTO - JULHO/2007 .

GRUPEMEF

\begin{tabular}{|c|c|c|}
\hline RANKING & SIGLA & LABORATÓRIO \\
\hline 172 & VLB & VITALAB \\
\hline 173 & SOB & SOBRAL \\
\hline 174 & SF2 & SANOFI PASTEUR \\
\hline 175 & ITD & 5 S IND E COM LTDA \\
\hline 176 & NVA & NOVAFARMA \\
\hline 177 & U_E & UNILEVER \\
\hline 178 & $\mathrm{AB}_{-}$ & ARBORETO \\
\hline 179 & $3 \mathrm{M}_{-}$ & 3M DO BRASIL \\
\hline 180 & $\mathrm{AS}_{-}$ & ASTER \\
\hline 181 & ATX & APOTEX \\
\hline 182 & GUH & GUNTHER \\
\hline 183 & L4S & LASA \\
\hline 184 & $\mathrm{AB} 3$ & ABL ANTIBIOTICOS \\
\hline 185 & IN2 & KIMBERLY \\
\hline 186 & L3B & LABORIS \\
\hline 187 & CIN & CINFA BRASIL \\
\hline 188 & OVB & OLVEBRA \\
\hline 189 & YAK & YAKULT \\
\hline 190 & $\mathrm{~A} 4 \mathrm{~T}$ & ABNAT \\
\hline 191 & $\mathrm{~A} 6 \mathrm{M}$ & AMO BRASIL \\
\hline 192 & A8N & API NUTRE \\
\hline 193 & A9N & ACTELION \\
\hline 194 & $\mathrm{AB} 4$ & AB FARMO \\
\hline 195 & $\overline{A C L}$ & ACLIMACAO \\
\hline 196 & AD2 & ADVANCED NUTRITION \\
\hline 197 & AFA & APIS FLORA \\
\hline 198 & AKK & AKAKIA BRASIL \\
\hline 199 & ALE & A LEIVAS LEITE \\
\hline 200 & ANE & ANEMIOTONICO \\
\hline
\end{tabular}




\section{BLOCO 1 - INFORMAÇÕES GERAIS SOBRE A EMPRESA}

1.1 Com relação ao executivo (administrador) da empresa:

É proprietário, sócio ou acionista

É um profissional contratado

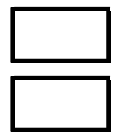

1.2 Estrutura Legal:

S/A

LTDA.

Sociedade Civil

Outra: (especificar)

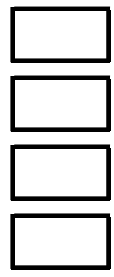

1.3 Origem do capital da empresa:

Nacional

Estrangeiro

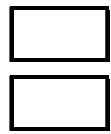

1.4 Com relação ao número de empresas:

Somente uma unidade

Pertence a um grupo nacional

Pertence a um grupo estrangeiro

Outro: (especificar)

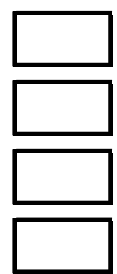

1.5 Tempo de atividade da empresa no Brasil:

Informar:

Faturamento Anual Bruto no Brasil (em milhares de reais) referentes a 2006

$1.6 \quad$ e 2007

1.6.1 Somente Divisão Farma:

2006 (Informar): \$

2007 (Informar): \$

1.6.2 Total Empresa:

2006 (Informar): \$

2007 (Informar): \$

1.7 Número de Empregados:

(incluir registrados, cooperados, autônomos, terceirizados etc.)

Informar:

1.8 Com relação ao destino das vendas:

Mercado Interno (informar o percentual \%)

Mercado Externo ～(informar o percentual \%) 


\section{BLOCO 2 - O SISTEMA DE INFORMAÇÃO CONTÁBIL-GERENCIAL}

2.1 A empresa possui uma área responsável pelo fornecimento de informações contábeis e gerenciais aos administradores?

$\square$ Sim, Controladoria<smiles></smiles>

Sim, outra (citar)

Por quê?

2.2 A empresa utiliza sistema de gestão integrado (software ) para registrar, armazenar, processar e organizar as informações geradas por todos os processos da empresa?

\begin{tabular}{l}
$\square \operatorname{Sim}$ \\
Qual? \\
\hline
\end{tabular}

2.3 A empresa elabora orçamento empresarial?

$\square$ Sim.

Qual é sua opinião sobre a adequação do processo atual?

$\square$ Não.

Por quê?

Não. Mas pretente elaborar no curto prazo.

\subsection{A empresa apura a Contabilidade Geral?}

$\square$ Sim. Contabilidade interna

Qual software utilizado para registro dos fatos contábeis?

$\square$ Não. Contabilidade externa

2.5 A empresa possui uma área responsável pela apuração dos custos?

$\square$ Sim

Qual software utilizado?

$\square$ Não 
2.6 Identificar os relatórios gerenciais GERADOS pela área financeira (ou controladoria) para serem utilizados pelos gestores na tomada de decisão e controle gerencial:

Demonstração do Resultado do Exercício (Empresa e Unidades de Negócios)

Balanço Patrimonial

Margem de Contribuição (Empresa, Produtos, Unidades de negócios)

$\square$ Demonstrativo de gastos por área de responsabilidade

$\square$ Fluxo de caixa

$\square$ Outros (citar)

2.7 Identificar os relatórios gerenciais EFETIVAMENTE UTILIZADOS pelos gestores para tomada de decisão e controle gerencial:

Demonstração do Resultado do Exercício (Empresa e Unidades de Negócios)

Balanço Patrimonial

Margem de Contribuição (Empresa, Produtos, Unidades de negócios)

Demonstrativo de gastos por área de responsabilidade

Fluxo de caixa

Outros (citar)

2.8 Na sua opinião, as informações geradas pelo sistema contábil-gerencial auxiliam os gestores no processo decisório e no controle gerencial?

Sim.

$\square$ Não.

Por quê?

2.9 Na sua opinião, o orçamento empresarial pode ser considerado uma ferramenta de apoio ao processo decisório e ao controle gerencial?

$\square$ Sim.<smiles>C1C[N+][Pb]C1</smiles>

2.10 Qual é a SUA PERCEPÇÃO com relação à OPINIÃO DOS DEMAIS GESTORES sobre o orçamento. Eles consideram o orçamento empresarial uma ferramenta de apoio ao processo decisório e ao controle gerencial?

$\square$ Sim.<smiles>C1CC[N+]C1</smiles>

Por quê? 


\section{BLOCO 3 - ETAPAS DO PROCESSO ORÇAMENTÁRIO}

* Este bloco deverá ser respondido somente se a empresa elabora o orçamento empresarial.

3.1 A empresa elabora plano de resultado de longo prazo, definindo as estratégias para o cumprimento dos objetivos de longo prazo?

$\square$ Sim. Elabora o plano de resultado de longo prazo e define estratégias.

$\square$ Somente elabora o plano de resultado de longo prazo.

$\square$ Somente define as estratégias.

$\square$ Não elabora o plano de resultado e nem define estratégias.

Por quê?

3.2 A empresa elabora plano de négócio, estabelecendo estratégias para cumprimento dos objetivos de curto prazo?

$\square \operatorname{Sim}$.

$\square$ Não, Por quê?

3.3 Antes do início do processo orçamentário são definidas as premissas básicas (Exemplo: taxa de inflação para o próximo ano, período de férias da força de vendas, taxa de reajuste dos salários, taxa de câmbio, taxa que vai reajustar os contrados, taxa e período para alteração no preço de venda, etc.)

$\square \operatorname{Sim}$

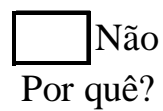

3.4 Orçamento de investimentos

3.4.1 A empresa elabora o orçamento das necessidades de investimento por centro de responsabilidade?

$\square$ Sim. Elabora o orçamento de investimento e por centro de responsabilidade.

$\square$ Somente elabora o orçamento de investimento, sem separar por centro de responsabilidade.

$\square$ Não elabora o orçamento de investimento/ Por quê?

3.4.2 O orçamento anual de investimento faz parte de um planejamento de longo prazo?<smiles>[AsH2][SnH3]</smiles>

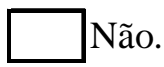

Por quê? 


\subsection{Orçamento de pessoal (headcount)}

3.5.1 Antes de calcular as despesas com pessoal é feita a projeção das necessidades pessoal (por quantidade), por centro de responsabilidade, informando: admissões, demissões, promoções, aumento de salário, inclusão/exclusão de benefícios, transfêrencias etc.?

$\square \operatorname{Sim}$.

$\square$ Não.
Por quê?

\subsection{Orçamento de Vendas}

3.6.1 A empresa faz a projeção contínua do volume de vendas? Qual é o sistema utilizado?

$\square \operatorname{Sim}$.

Software

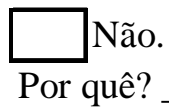

Por quê?

3.6.2 Existe um indicador de performance ou de desempenho baseado na acuracidade (assertividade) da projeção da quantidade a ser vendida?

$\square$ Sim.

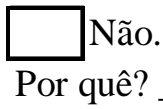

3.6.3 Com relação ao grau máximo de detalhamento, o orçamento de vendas é elaborado:

$\square$ Pelo valor total da empresa.

Por unidade de negócio.

$\square$ Por região de vendas.

$\square$ Por produto.

$\square$ Por apresentação do produto.

$\square$ Todas estas formas.

$\square$ Outras. (citar)

3.6.4 Qual é a periodicidade do acompanhamento e controle do orçamento de vendas?

$\square$ Mensalmente

$\square$ Semestral

$\square$ Quinzenalmente

$\square$ Outras. (citar) 


\subsection{Orçamento dos Custos dos Produtos}

3.7.1 Qual é a origem dos produtos acabados?

$\square$ Fabricação interna

$\square$ Comprados da matriz

$\square$ Comprados de terceiros

3.7.2 Como é projetado o custo unitários dos produtos acabados?

$\square$ Determinação do custo-padrão pela matriz.

$\square$ Custo-padrão atual reajustado.

$\square$ Custos projetados pela fábrica e alocados aos produtos.

$\square$ Outros. (citar)

\subsection{Orçamento despesas alocadas por produto}

3.8.1 Assinale os gastos cujos valores são lançados contra o resultado do produto.

$\square$ Distribuição de amostras

$\square$ Promoção e propaganda

$\square$ Despesas de vendas (comissões, brindes)

$\square$ Despesas de distribuição (fretes)

$\square$ Testes clínicos (pós lançamento do produto)

$\square$ Outros. (citar)

\subsection{Orçamento despesas fixas da força de vendas}

310.1 A empresa elabora orçamento das despesas gerais da força de vendas por centro de responsabilidade?

$\square \operatorname{Sim}$.

$\square$ Não.
Por quê?

\subsection{Orçamento de despesas fixas de Marketing}

3.11.1 A empresa elabora orçamento das despesas gerais de marketing (salários e estrutura do staff) por centro de responsabilidade?

$\square \operatorname{Sim}$.

Não.

Por quê? 


\subsection{Orçamento de despesas gerais e administrativas}

3.12.1 A empresa elabora orçamento das despesas gerais e administrativas (salários e estrutura física) por centro de responsabilidade?

Sim.

Não.

Por quê?

3.12.2 Algumas despesas gerais e administrativas são transferidas para as outras áreas, utilizando-se algum critério de rateio?

$\square \operatorname{Sim}$.

$\square$ Não.

Quais despesas?

Por quê?

\subsection{Orçamento de gastos com pesquisa e desenvolvimento}

3.14.1 A empresa elabora orçamento dos gastos realizados com pesquisa e desenvolvimento de produtos?

$\square \operatorname{Sim}$.

Ativo Diferido ou Despesa?

\subsection{Orçamento de caixa}

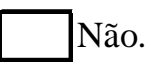

Por quê?

3.15.1 A empresa elabora o orçamento ANUAL de caixa?

$\square$ Sim.

$\square$ Não.

Por quê?

3.15.2 A empresa utiliza a projeção contínua de caixa para administrar suas sobras ou insuficiências de dinheiro em tempo hábil? Como é feito o controle?

$\square$ Sim.<smiles>[C+]1CC[Pb][N+]1</smiles>

3.15.3 Visando o cumprimento orçamento de caixa, a empresa possui procedimentos (normas) estabelecendo prazo mínimo (em dias) para que a nota fiscal chegue até o Contas a Pagar?

$\square \operatorname{Sim}$.

$$
\begin{aligned}
& \square \text { Não. } \\
& \text { Por quê? }
\end{aligned}
$$

\section{CONTROLE ORÇAMENTÁRIO}

\subsection{Acompanhamento do orçado $\mathrm{x}$ realizado}

3.16.1 Existe uma reunião formal de acompanhamento do resultado, entre presidente e diretorias, onde serão analisadas as causas de eventuais desvios e definidas ações corretivas, visando o cumprimento dos objetivos empresariais? Qual é a periodicidade?

\footnotetext{
$\square$ Sim. Periodicidade
} 


\section{BLOCO 4 - AVALIAÇÃO DO PROCESSO ORÇAMENTÁRIO}

Dê nota de 0 a 10 (zero a dez) em relação ao grau de concordância com cada uma das assertivas a seguir:

\subsection{Envolvimento administrativo}

4.1.1 A alta administração acredita que o processo de planejamento como um todo traz benefícios para a empresa.

\begin{tabular}{|l|l|l|l|l|l|l|l|l|l|l|}
\hline 10 & 9 & 8 & 7 & 6 & 5 & 4 & 3 & 2 & 1 & 0 \\
\hline
\end{tabular}

4.1.2 Todos os colaboradores que possuem responsabilidades administrativas estão envolvidos no processo orçamentário.

\begin{tabular}{|l|l|l|l|l|l|l|l|l|l|l|}
\hline 10 & 9 & 8 & 7 & 6 & 5 & 4 & 3 & 2 & 1 & 0 \\
\hline
\end{tabular}

\subsection{Adaptação organizacional}

4.2.1 A estrutura organizacional da empresa está claramente definida, apresentando os níveis de autoridade e suas responsabilidades.

\begin{tabular}{|l|l|l|l|l|l|l|l|l|l|l|}
\hline 10 & 9 & 8 & 7 & 6 & 5 & 4 & 3 & 2 & 1 & 0 \\
\hline
\end{tabular}

4.2.2 A estrutura adotada na elaboração do planejamento coincide com as responsabilidades dos gestores.

\begin{tabular}{|l|l|l|l|l|l|l|l|l|l|l|}
\hline 10 & 9 & 8 & 7 & 6 & 5 & 4 & 3 & 2 & 1 & 0 \\
\hline
\end{tabular}

\subsection{Contabilidade por área de respnsabilidade}

4.3.1 O sistema contábil é capaz de fornecer informações financeiras por conta contábil, centros de responsabilidade, por produto e por unidade de negócios.

\begin{tabular}{|l|l|l|l|l|l|l|l|l|l|l|}
\hline 10 & 9 & 8 & 7 & 6 & 5 & 4 & 3 & 2 & 1 & 0 \\
\hline
\end{tabular}

\subsection{Orientação para objetivos}

4.4.1 Os objetivos e metas da empresa são definidos por área de responsabilidade e esta, por sua vez, repassa para seus subordinados.

\begin{tabular}{|l|l|l|l|l|l|l|l|l|l|l|}
\hline 10 & 9 & 8 & 7 & 6 & 5 & 4 & 3 & 2 & 1 & 0 \\
\hline
\end{tabular}

\subsection{Comunicação integral}

4.5.1 O sistema de informação da empresa atende as necessidades dos usuários em diferentes níveis.

\begin{tabular}{|l|l|l|l|l|l|l|l|l|l|l|}
\hline 10 & 9 & 8 & 7 & 6 & 5 & 4 & 3 & 2 & 1 & 0 \\
\hline
\end{tabular}

4.5.2 O orçamento, elaborado e aprovado, é divulgado para os responsáveis antes do início de sua execução.

\begin{tabular}{|l|l|l|l|l|l|l|l|l|l|l|}
\hline 10 & 9 & 8 & 7 & 6 & 5 & 4 & 3 & 2 & 1 & 0 \\
\hline
\end{tabular}

4.5.3 São realizadas reuniões periódicas para avaliação dos resultados, onde são analisadas as variações (previsto $\mathrm{x}$ realizado)

\begin{tabular}{|l|l|l|l|l|l|l|l|l|l|l|}
\hline 10 & 9 & 8 & 7 & 6 & 5 & 4 & 3 & 2 & 1 & 0 \\
\hline
\end{tabular}




\subsection{Expectativas realistas}

4.6.1 A definição dos objetivos e metas da empresa é apoiada nas expectativas realistas do ambiente externo e interno, para o período orçado.

\begin{tabular}{|l|l|l|l|l|l|l|l|l|l|l|}
\hline 10 & 9 & 8 & 7 & 6 & 5 & 4 & 3 & 2 & 1 & 0 \\
\hline
\end{tabular}

\subsection{Oportunidade}

4.7.1 A empresa possui um calendário formal para elaboração do orçamento, incluindo revisões periódicas.

\begin{tabular}{|l|l|l|l|l|l|l|l|l|l|l|}
\hline 10 & 9 & 8 & 7 & 6 & 5 & 4 & 3 & 2 & 1 & 0 \\
\hline
\end{tabular}

\subsection{Aplicação flexível}

4.8.1 O orçamento é flexível, podendo ser alterado para atender novas necessidades.

\begin{tabular}{|l|l|l|l|l|l|l|l|l|l|l|}
\hline 10 & 9 & 8 & 7 & 6 & 5 & 4 & 3 & 2 & 1 & 0 \\
\hline
\end{tabular}

\subsection{Reconhecimento do esforço individual e do grupo}

4.9.1 A empresa possui um programa de incentivos que motiva os colaboradores de cada uma das áreas?

\begin{tabular}{|l|l|l|l|l|l|l|l|l|l|l|}
\hline 10 & 9 & 8 & 7 & 6 & 5 & 4 & 3 & 2 & 1 & 0 \\
\hline
\end{tabular}

\subsection{Acompanhamento}

4.10.1 A empresa acompanha periodicamente a evolução do desempenho, comparando os valores projetados com os realizados.

\begin{tabular}{|l|l|l|l|l|l|l|l|l|l|l|}
\hline 10 & 9 & 8 & 7 & 6 & 5 & 4 & 3 & 2 & 1 & 0 \\
\hline
\end{tabular}

4.10.2 Os relatórios de acompanhamento e controle são disponibilidados em até 5 dias úteis após o fechamento mensal, para que os gestores tenham tempo hábil para correção das variações.

\begin{tabular}{|l|l|l|l|l|l|l|l|l|l|l|}
\hline 10 & 9 & 8 & 7 & 6 & 5 & 4 & 3 & 2 & 1 & 0 \\
\hline
\end{tabular}

4.10.3 Caso haja variações expressivas, estas são analisadas e ações corretivas são adotadas.

\begin{tabular}{|l|l|l|l|l|l|l|l|l|l|l|}
\hline 10 & 9 & 8 & 7 & 6 & 5 & 4 & 3 & 2 & 1 & 0 \\
\hline
\end{tabular}

